\title{
Tarihsel Süreçte Yaşanan Pandemilerin Ekonomik ve Sosyal Etkileri
}

\section{Economic and Social Effects of Pandemics Experienced in the Historical Process}

\author{
Armağan TÜRK a*, Berna AK BİNGÜL ${ }^{\mathrm{b}}$, Rengin $\mathrm{AK}^{\mathrm{c}}$ \\ a Dr. Ögr. Üyesi, Bandırma Onyedi Eylül Üniversitesi İ̈BF, İktisat Bölümü, Balıkesir / TÜRKIYYE \\ ORCID: 0000-0002-6646-9333 \\ b Dr. Öğr. Üyesi, Kırklareli Üniversitesi, Uygulamalı Bilimler Fakültesi, Finans ve Bankacılık Bölümü, Kırklareli / TÜRKIYE \\ ORCID: 0000-0002-2813-2780 \\ ${ }^{c}$ Prof.Dr., Kırklareli Üniversitesi İ̈BF İktisat Bölümü, Kırklareli / TÜRKIYE \\ ORCID: 0000-0003-0364-9975
}

\section{A K A L E B İL G İ S İ}

Makale Geçmişi:

Başvuru tarihi: 8 Temmuz 2020

Kabul tarihi: 12 Ekim 2020

Anahtar Kelimeler:

Salgin,

Pandemi,

Covid-19,

Coronavirüs,

Ekonomik Etki

\section{ART ICLE INFO}

Article History:

Received July 08,2020

Accepted October 12, 2020

Keywords:

Epidemic,

Pandemic,

Covid-19,

Coronavirus,

Economic Impact

\section{ÖZ}

Salgınlar tarihin her döneminde toplumsal etki yaratmıștır. Yakın bir tarihe kadar salgınların neden kaynaklandığı konusundaki bilgi eksikliği salgınların toplum üzerindeki etkisini arttırmış ve bunun sonucu olarak çıktığı bölgelerde yaygınlık göstererek kitlesel ölümlere yol açmıştır. Ölüm ve hastalıkların yanı sıra, salgınlar insanların sosyal yasantılarını, tüketim alıskanlıklarını, yaşam tarzlarını ve ekonomik faaliyetlerini de etkilemiștir. Salgınların etkisinin bu kadar büyük olmasındaki temel neden ise, salgının ne zaman çıkacağı ne kadar yayılacağı ve ne kadar süreceği konusunda yaşanan belirsizliktir.

Küreselleşme olgusu ve yarattı̆̆ı ticari entegrasyon sonucu ülkeler arasındaki ticari ilişkilerin gelişmesi, ticari ve ticari olmayan seyahatlerin artması salgınların ortaya çıktıkları yerden hızlı bir şekilde dünya geneline yayılmasına neden olmuştur. Salgınların sosyal yaşantı üzerindeki olumsuz etkileri olmakla birlikte daha çok ekonomik kayıplarından dolayı ekonomik etkileri üzerinde durulmuştur. Ticari entegrasyon sonucunda ülkelerin ekonomik kayıpları ticari ilişkilerden dolayı diğer ülkeleri de etkilemektedir. Ekonomik kayıpların artması sosyal yașantının ekonomik nedenlerden dolayı da değişmesine yol açmıştır. Literatürde yer alan çalışmalarda salgınların genelde ülkelerin ekonomik gücünü zayıflatarak kriz ortamı yarattığı görülmektedir. Salgınların ülkelerin ve küresel ekonomi üzerindeki doğrudan etkileri yanında dolaylı etkileri de oldukça önemlidir. Salgınların ekonomiler üzerindeki doğrudan etkilerinin hesaplanması daha kolay iken dolaylı etkilerinin tam olarak hesaplanması mümkün olmamaktadır. Ayrıca doğrudan etkiler salgın süresince görülürken dolaylı etkiler daha uzun bir döneme yayllabilmektedir.

$\mathrm{Bu}$ çalışmada, tarihsel süreç içerisinde ülkeleri derinden etkileyen küresel salgınlar ele alınmıștır. Bu kapsamda salgınların ülkelerin ekonomik ve sosyal yapıları üzerindeki değişim ve etkileri değerlendirilmiş ve olası salgınlara karşı öngörüde bulunulması amaçlanmıştır.

\section{A B S T R A C T}

Epidemics have had a social impact in every period of history. Until recently, the lack of information about the cause of epidemics has increased the impact of epidemics on society and has caused widespread deaths in the regions where it originated. In addition to death and illness, epidemics have also affected people's social lives, consumption habits, lifestyles, and economic activities. The main reason why the epidemics have profound impacts is the uncertainty about when the epidemic will take place, how much it will spread, and how long it will continue.

As a result of the globalization phenomenon and the commercial integration it created, the development of commercial relations between countries and the increase of commercial and non-commercial travels caused the epidemics to spread rapidly worldwide. Although epidemics have negative effects on social life, their economic effects are mostly emphasized due to their economic losses. Economic losses of countries as a result of commercial integration also affect other countries due to commercial relations. The increase in economic losses caused the social life to change due to economic reasons. In the studies in the literature, it is seen that epidemics generally create a crisis by weakening the economic power of countries. Besides the direct effects of epidemics on countries and the global economy, indirect effects of them are also crucial. While it is easier to calculate the direct effects of epidemics on economies, it is not possible to calculate the indirect effects exactly. In addition, while direct effects are seen during the epidemic, indirect effects can be spread over a longer period.

In this study, global epidemics that have affected countries deeply in the historical process are discussed. In this context, the changes and effects of epidemics on the economic and social structures of the countries were evaluated and it was aimed to predict possible epidemics.

\footnotetext{
* Sorumlu yazar/Corresponding author.

e-posta: aturk@bandirma.edu.tr
} 


\section{EXTENDED ABSTRACT}

Crises are very important for both national economies and global economy. Events that change the normal course of economies have many effects. Crises affecting economies are mostly economic, but sometimes they can also be through different channels. When epidemics are examined in the historical process, they have many effects on the economy. Although it varies according to the conditions of the period when epidemics occurred, outbreaks have always affected societies.

The most important crisis after the Mortgage crisis that emerged in the United States in 2007 and spread all over the world is seen as Covid19. The epidemic, which emerged in China and spread in a short time, affected the whole world. When it first appeared, it could not have been foreseen that it could turn into such a disaster. Incomplete and incorrect practices related to the epidemic made the problem global in a short time. Apart from the economic and social effects of the epidemic, it has been observed that even developed economies are not sufficiently prepared for such an epidemic.

Since 2019, when the Covid19 outbreak emerged, it has had very different effects on countries. While some countries pay the effect of not taking adequate measures at very high costs, in some countries they have reduced the effects and costs of the epidemic by taking the necessary measures on time. Uncertainties regarding the epidemic still remain the most important problem for many countries. These uncertainties affect and change social life as well as the economies of countries. The epidemic examples discussed in this study are important for understanding the current outbreak and for future outbreaks. Although outbreaks have occurred in different periods and conditions, they have similar aspects.

The first studies on the economic impact of epidemics have been on medical response and healthcare costs. This is seen more or less in every period of history. Although there is not much statistical information about the first epidemics we dealt with, these and similar conclusions can be drawn from historical records. Later, the microeconomic effects of epidemics began to be emphasized. The effects of the epidemics on economic magnitudes such as household income and company profits were discussed. Total economic losses were calculated and costs were started to be deducted. As a result, necessary strategies and action plans have been developed to reduce costs. One of the issues emphasized when dealing with the effects of epidemics has been its effects on different segments of the society. While outbreaks affect different segments of the society differently, they have also affected the relative importance of these segments. Another feature of epidemics in this context is that every social segment has been caught in an epidemic. In other words, epidemics have infected not only the poor but also the aristocratic class. Many people in this class fell ill from the epidemic and died. Despite the developments in the field of health, this can be seen in the covid19 outbreak. The deepening of the effects of epidemics has increased with the concentration of people in certain areas. When the epidemic occurs, more densely populated places attract attention.

The diversification and increase of the effects of epidemics on society has brought different views on epidemics. The Covid-19 coronavirus epidemic has also turned into a worldwide crisis, causing many changes. In addition to changes in social life, important economic changes have been experienced. The slowdown in other developed economies, especially China, which is one of the most important economies of the world, affected the whole world. In addition to the social effects caused by epidemic diseases, there are also social effects caused by the negativities in the economy.

The epidemic that was recorded in history and caused the first mass deaths was the plague of Antoninus. It is a major epidemic that Roman soldiers carried to their countries on their return to the Near East expeditions between 165-180 AD. Similarly, the most known way of spreading epidemics today is people's travels. The most important effect of this epidemic is the weakening of the country in terms of agricultural production. As a result, the effect of the epidemic has increased even more. After the epidemic, the structure of agriculture and trade has changed. In other words, the epidemic has changed the structure of the current economy. Another effect of this epidemic is that people migrate from where they are located. Migration has led to the weakening and disappearance of commercial centers.

The primary effects of the First (Justinian) Plague Outbreak and its subsequent plague epidemics were again economic. This epidemic has affected important trading ports. The spread of the epidemic has also been from these port cities. The plague epidemic affected a large part of the population in terms of the period when it emerged and caused deaths. One of the most important features of this epidemic is medical deficiencies against this epidemic. In this epidemic, the high rate of deaths caused a decrease in the workforce and affected the economy. Especially the decrease in the population engaged in agricultural activities has increased the deaths due to insufficient agricultural products. The plague brought along a period of great instability with famine. Another of the financial problems is the weakening gold coins. The Roman administration minted lower quality gold coins in response to the sharp decline in their income, and copper coins lost their stability during this period. The effects of epidemics up until the industrial revolution are quite similar. The effects of the population decrease due to medical insufficiency and the decrease in agriculture and migration are important. The different issue regarding the epidemics in this period is that the virus that caused the epidemic was not identified, but it was used for biological warfare.

In the outbreaks seen after the industrial revolution, it is seen that the rate of spread of epidemics has increased. However, advances in medicine have helped to determine the causes of the epidemic faster. Although the causes of the epidemics have been determined rapidly, the increase in the number of people traveling has accelerated the spread of the epidemics. Generally speaking, epidemics after the industrial revolution are mostly of Asian origin. With the increase in global trade, the spread of epidemics has accelerated and its impact on countries and the world economy has increased. Different results were obtained in studies on the economic effects of epidemics that occurred after the industrial revolution. The impacts stated in these studies can be summarized as unemployment, decrease in income, decrease in production, decrease in agricultural productivity, absenteeism in schools and workplaces, increase in health expenditures, decrease in tourism revenues, contraction in service sector, decrease in oil demand, slowdown in growth and slowdown in global economy. 


\section{GíRiş}

Amerika'da 2007 yılında başlayıp tüm dünyaya yayılan 2008-09 Büyük Durgunluğundan bu yana en önemli jeopolitik olay Çin'de başlayıp tüm dünyaya yayılan Covid-19 salgınıdır. İlk başlarda bu durumun sadece Çin veya İtalya'nın sorunu olarak görülmesi sorunun derinleşmesine yol açmıştır. Artık bu salgın bazı rejimlerin itibarını ve belki de hayatta kalmasını tehdit etmiştir. 2100 yılına kadar dünya nüfusu 7,7'den 11 milyar kişiye yükselirken, insanlar gelişmekte olan ülkelerdeki yaşamla yakın temasta bulunmakta ve Soğuk Savaş'ın sona ermesinden bu yana kıtalar arası havayolu ile yolculuklar çok büyük miktarda artmıştır. Kıtalararası bu yolculukların artması pandemilerin (salgınların) neoMalthus dünyasına doğal bir refakatçi olmuştur. Bu tür geniş kapsamlı olayların birçok etkisi olmakla birlikte çalışmamızda üzerinde duracağımız etkiler ekonomik ve sosyal etkilerle sınırlandırılacaktır.

Salgınların ekonomik etkileri üzerindeki ilk çalışmalar tıbbi müdahale ve sağlık maliyetleri üzerinde olmuştur. Bu çalışmalarda hasta başına düşen maliyet hesaplanarak salgının toplam maliyeti hesaplanmaya çalışılmıştır. Bu çalışmalar sadece sağlık sektörü harcamaları üzerinde yoğunlaşmıştır (Roberts, vd., 2003, s.2-3). Daha sonra salgınların mikro ekonomik etkileri üzerinde durulmaya başlanmıştır. Salgınların hanehalkı geliri ve firma kârları gibi ekonomik büyüklükler üzerindeki etkileri ele alınmış. Toplam ekonomik kayıplar hesaplanarak maliyetler çıkartılmaya başlanmıştır. Bunun sonucu olarak maliyetleri azaltmak için gerekli stratejiler ve eylem planları geliştirilmeye çalışılmıştır. Hastalıkların hanehalkı, firma ve devletin işleyiş̧i üzerinde önemli etkileri yaratmakta ve bu etkilerin boyutu hesaplanmaya çalışılmaktadır (WHO, 2009).

\section{Tarihsel Süreçte Yaşanan Pandemiler}

Salgın hastalıklar insanlık tarihinin her döneminde toplumları etkileyen önemli bir unsur olmuştur. Toplumların salgınlardan etkilenmesi toplumu oluşturun herkesim için aynı şiddette olmamıştır. Salgınlardan bazı kesimler daha çok etkilenirken bazıları daha az etkilenmiştir. Sonuç olarak, büyük salgınların toplumun sonraki evrimi üzerinde büyük etkileri olması muhtemeldir. Salgınların toplumlar üzerindeki etkileri her alanda görülmekle birlikte bu çalışma özellikle ekonomik etkiler üzerinde yoğunlaşmıştır. Tarihsel süreç içerisinde insanların topluluk olarak yaşamaya başlaması ya da kentleşme salgınların etkilerini arttırmış ve çeşitlendirmiştir. Salgınların toplum üzerindeki etkilerinin çeşitlenmesi ve artması salgınlara yönelik farklı görüşleri de beraberinde getirmiştir. Son Covid-19 koronavirüs salgını da dünya çapında bir krize dönerek birçok değişim meydana getirmiştir. Sosyal yaşantıdaki değişmeler yanında önemli ekonomik değişmelerde yaşanmıştır. Dünyanın en önemli ekonomilerinden biri olan Çin başta olmak üzere diğer gelişmiş ekonomilerde görülen yavaşlama tüm dünyayı etkilemiştir. Salgın hastalıkların yarattığı sosyal etkiler yanında ekonomideki olumsuzlukların getirdiği sosyal etkilerde bulunmaktadır. Bundan dolayı ekonomik etkilerle sosyal etkiler iç içe geçmiş ve birbirini zincirleme olarak etkiler durumdadır. Bu çerçevede tarihte yaşanan önemli salgınlar, ekonomik etkileri başta olmak üzere sosyal etkileri de ele alınmıştır. Aşağıdaki tabloda çalışmada ele alınacak salgınlar tarih süreç içinde listelenmiştir.

Tablo 1: Tarihsel Süreçte Salgınlar

\begin{tabular}{|l|l|r|}
\hline Zaman & Salgın & Tahmini Ölüm Sayısı \\
\hline $165-180$ & Antonine Salgını & 5 milyon \\
\hline $541-542$ & 1.Veba Salgını & 30-50milyon \\
\hline $735-737$ & Japonya Çiçek Salgını & 1 milyon \\
\hline $1347-1351$ & 2.Veba Salgını & 200 milyon \\
\hline $1520-$ & Yeni Dünya Çiçek Salgını & 56 milyon \\
\hline $1629-1631$ & İtalya Vebası & 1 milyon \\
\hline $1665-$ & Londra Büyük Vebası & 100 bin \\
\hline $1817-1923$ & Kolera Pandemileri 1-6 & $>1$ milyon \\
\hline $1885-$ & 3.Veba Salgını & 12 milyon \\
\hline 1800 sonu & Sarı Humma Salgını & $100-150$ bin \\
\hline $1889-1890$ & Rus Gribi & 1 milyon \\
\hline $1918-1919$ & İspanyol Gribi & $40-50$ milyon \\
\hline
\end{tabular}




\begin{tabular}{|c|c|c|}
\hline $1957-1958$ & Asya Gribi & 1,1 milyon \\
\hline $1968-1970$ & Hong Kong Gribi & 1 milyon \\
\hline 1981-Günümüz & HIV/AIDS & $>35$ milyon \\
\hline $2002-2004$ & SARS & 770 \\
\hline $2009-2010$ & Domuz Gribi & 200.000 \\
\hline 2014-2016 & Ebola & 11.000 \\
\hline 2015-Günümüz & MERS & 850 \\
\hline 2019-Günümüz & COVID-19 & $1.113 .909(19.10 .2020)$ \\
\hline
\end{tabular}

Kaynak: Yazarlar tarafindan oluşturulmuştur.

\section{Antoninus Vebasi (165-180)}

Tarihte kayıtlara geçen ve ilk kitlesel ölümlere yol açan salgın, Antoninus vebasıdır. MS 165180 yılları arasında Romalı askerlerin Yakın Doğu seferleri dönüşünde ülkelerine taşıdığı büyük bir salgındır. Roma İmparatoru Lucius Verus'un ölümü sonrasında salgın tekrar nüksetmiş ve yaşanan salgın dokuz yıl sonra günde 2000 kişini ölümüne yol açmıştır. Bölge nüfusunun üçte birine karşıllık gelen yaklaşık 5 milyon insanın salgından ölmesine neden olmuştur (BBC, 2005).

Veba salgını sonrası azalan nüfus ve askeri kayıplar nedeniyle Roma İmparatorluğu Antoninler dönemi hem ekonomik hem de askeri olarak zayıflamaya başlamıştır. Roma ekonomisi Akdeniz bölgesindeki nüfusu ve lejyonları besleyen tarıma dayalı bir ekonomiye sahip olup tarım ve ticaret sadece küçük ölçekli sanayi üretimi şeklindeydi. 172-180 yılları arasında aralıklarla devam eden Marcomanni savaşları ekonomik önlemleri de beraberinde getirmiş ve salgının neden olduğu can kayıplarını artırmıştır (Karakuş, 2018, s.40).

Salgına bağlı ölüm veya göç nedeniyle Roma İmparatorluğunun Mısır köylerinde kayıtlı mükellef sayısında $\% 33$ ile $\% 93$ arasında bir düşüş yaşanmış ve tarımsal kiralama sözleşmelerinin türünde bir genişleme olmuştur. $\mathrm{Bu}$ durum işgücü eksikliğinin bir göstergesi olarak yorumlanmıştır. Salgının başlangıcını takip eden yıllarda ticari belgelerde \%40 azalma olmuştur. İmparatorluğun önemli ekonomik ve kültür merkezlerinden olan Nil vadisinde tarımsal vergilerde artıştan dolayı kırsal alandan kente doğru göç olmuş ve bu durum önemli tarımsal ürünler olan tahıl, yağ ve şarap üretimini azaltmıştır. Kent nüfusunun artmasıyla birlikte tarımsal ürünlere olan talep artarken arzın azlığı sorunları daha da derinleştirmiş ve aynı zamanda kentlerde yeni iş kollarının ortaya çıkmasına yol açmıştır. Salgının bir diğer etkisi de önemli ticaret yolları üzerinde gözlemlenmiş ve İmparatorluğun önemli ticaret merkezleri olan Şam ve Antakya'da ticaret neredeyse durma noktasına gelmiştir (Sabbatini ve Sirio, 2009, s.269).

\section{Birinci (Justinianus) Veba Salgını (541-542)}

Tarihteki en büyük veba salgınlarından biri olup ilk salgında yaklaşık 25 milyon kişi ölümüne neden olan Justinianus Veba Salgını, bir pandemi olup Bizans İmparatorluğu başta olmak üzere başkent Konstantinopolis, Sasani İmparatorluğu ve Akdeniz liman şehirlerini etkilemiştir. Altıncı yüzyılın vebas1, ilk olarak milattan sonra 541'de Misır'da ortaya çıkmış, 542'de Doğu Roma İmparatorluğu'nun başkenti olan Konstantinopolis'e daha sonra İmparatorluktan Güney Avrupa, Pers'e (İran) ve içlerine yayılmıştır. Salgın zaman zaman azalsa da bu bölgede sekizinci yüzyıla kadar etkili olmuştur (Snell,2019). Bu salgının en önemli özelliği tarihteki güvenilir kayıtları olan ilk salgındır.

Salgın öncesi açlıktan ve salgından ölenlerin sayısı tam olarak bilinememekle birlikte bazı kaynaklarda günde 10.000 kişinin öldüğü kaydedilmiştir. En yoğun ölümlerin yaşandığı imparatorluğun başkentinde yaşanan kitlesel ölümler ekonomiyi ve nüfusun genel psikolojik durumunu ciddi şekilde etkilemiştir. Justinianus Vebası nedeniyle Doğu Roma İmparatorluğunda nüfusun keskin bir şekilde düşmesi, iş gücü sıkıntısına yol açmış ve bu da işgücü maliyetinde artışa neden oldu. Sonuç olarak maliyetlerin artmasıyla enflasyon yükselmiştir (Snell, 2019). İmparatorluğun finansal sistemi toprağın ve kişilerin vergilendirilmesine dayanmaktaydı. Toprak sahiplerinin ölümü kalanlarında veba nedeniyle mahsulle ilgilenmemeleri tarım üzerinde negatif etki yaratarak gıda üretiminin azalmasına ve şehirlerde kıtlıklara neden olmuştur. Nüfusun azalmasıyla birlikte aynı vergilerin daha küçük bir gruba yüklenmesi bir finansal krize yol açmıştır. Veba kıtlıkla birlikte büyük bir istikrarsızlık dönemini de beraberinde getirmiştir. Finansal sorunların bir diğeri de zayıflayan altın sikkelerdir. Roma yönetimi, 
gelirlerindeki sert düşüşe tepki olarak daha düşük kaliteli altın paralar basmış, bakır sikkeler de bu dönemde istikrarlarını yitirmiştir. Arz sorununu gidermek amacıyla tarımsal alanlar üzerinde düzenlemeler yapılmıştır (Meier, 2016, s.275-281). Dolayısıyla salgın tarım ve ticaretin bozulmasına ve vergi gelirlerinin azalmasına neden olmuştur.

\section{Japon Çiçek Hastalığı Salgını (735-737)}

Japon çiçek hastalığı salgını 735 yılında Tokyo'da ortaya çıkmış ve yayılım göstererek iki yıl içinde yaklaşık bir milyon kişinin ölümüne neden olmuştur. Japon nüfusunun yaklaşık üçte birinin öldüğü salgında ölenlerin çoğu çocuk olmakla birlikte aristokratların ölümü de oldukça fazlaydı. Japonya ile Asya ana karası arasındaki ticaretin artması hastalık ve salgınların ülkeye girişini arttırmıştır. Çiçek hastalığının da ülkeye Japon balıkçılar tarafından getirildiği tahmin edilmektedir. Kore yarımadasında tarım alanlarının bulunduğu bölgelerde hastalığın yayılması tarımsal ürünlerde verim düşüşüne ve kıtlığa yol açmıştır. Japon yetkililerin hastalığın bulunduğu Kore yarımadasındaki bölgeden geçmeleri hastalığın ülke geneline yayılmasında etkili olmuştur. Japonya'da vergi muafiyetlerinin uzatılması hastalığın etkisinin yayıldığını göstermektedir. Hastalık Japonya nüfusunun yaklaşık olarak \%25-35 ini etkilemiştir. Salgın, bir yandan ölümle, diğer yandan göçlerin artmasıyla çalışabilir nüfus üzerinde olumsuz etki yaratmıştır. Emeğin büyük ölçüde yer değiştirmesi inşaat ve tarım sektörünü etkilemiştir. Özellikle pirinç tarımı bu yer değiştirmeden çok etkilenmiştir. Bu sorunu çözmek için vergi muafiyetleri yanında çalışmak isteyenlere özel arazi mülkiyeti sunulmuştur (Farris, 2009, s.36-37).

Nüfus durağanlığına yol açan ikinci faktör, sekizinci yüzyılın en zengin ve finansal açıdan en önemli bölgesi olan Kinai'yi (Japonya'nın en gelişmiş bölgesi) çevreleyen ekolojik bozulmaydı. Salgın sonrası Budizmin Japonya'da yayılmasına destek vermek amaciyla İmparator tarafindan yaptırılan tapınak, mabet ve aristokrat malikaneleri için kereste ve çatı kiremidi imalatı kızıl çam ormanlarını tüketmiş ve bunun sonucu olarak Kinai ve çevresindeki ağaçsız dağlar daha az yağmur ve daha fazla erozyon üretmeğe başlamıştı. Yaşanan kuraklıkla birlikte kuru iklimin etkilerinin artması çiftçilerin yeni yerlere göç etmesine neden olmuştur. Ekonomideki bir diğer sorunda paranın değer kaybetmesiydi. Ticareti kolaylaştırmak için çıkartılan bakır paralar salgında değer kaybetmiş sonraki dönemlerde para arzının arttırılması paranın değersiz hale gelmesine neden olmuştur (Farris, 2009, s.40-42).

\section{İkinci (Büyük) Veba Salgını (1347-1351)}

İkinci veba salgını ya da büyük veba salgını Asya'da başlayarak 1340'lı yılların sonunda Avrupa'ya ulaşmış bir salgındır. Salgın Avrupa'da 1347-1351 yılları arasında büyük can kayıplarına yol açmıştır. Salgında yaklaşık olarak 200 milyon kişinin öldüğü tahmin edilmektedir. Salgın çoğunlukla yoksulları etkilemekle birlikte vebanın yayılmasıyla birlikte aristokrat sınıf ta etkilenmiştir. Hastalık ilk olarak 1330'lu yıllarda Çin'de ortaya çıktıktan sonra 1346 yılında Kırıma, buradan da ticaret gemileri vasıtasıyla İstanbul, Mısır ve Suriye’ye yayılmıştır. Veba, Akdeniz ticareti nedeniyle Sicilya'ya, Afrika'nın kuzeyine ve Avrupa'ya ulaştıktan sonra hızlı bir şekilde Avrupa'nın tamamına, İngiltere ve Rusya'ya yayılmışıtır (Pamuk, 2020). Vebanın Avrupa'da ortaya çıkış zamanı Avrupa ekonomik tarihi açısından oldukça önemlidir. Veba öncesi Avrupa kentsel yaşamın canlandığı, uzun mesafeli ticaretin yeniden canlandığ 1 , iş ve üretimin geliştiği, manastır tarımının olgunlaştığı ve nüfusun arttığ 1 bir dönemdeydi. Veba eş zamanlı olarak Avrupa'da hem ekonomik durgunluğa hem de depresif bir toplumun ortaya çıkmasına yol açmıştır.

Veba, büyük ölçüde sosyal ve ekonomik etkiler yarattı. Veba sonrası insanlar sosyalleşmeden uzaklaştılar. Ayrıca din adamlarının ölümü ve salgın için dua edilmemesi dine olan inancı da azalttı. Malları ticaret yoluyla tedarik etmek ve üretmek çok zor (ve tehlikeli) olduğundan hem yerel olarak üretilen hem de uzaktan ithal edilen malların fiyatları hızla yükselmiş dolayısıyla ekonomide ani ve aşırı enflasyon yaşandı. Hastalık ve ölüm nedeniyle işgücünün azalması işgücü maliyetlerin artmasına neden oldu. Arazi kullanma talebindeki artış birçok ülkede toprak düzenini değiştirmiştir. Lordlar, durumu köylüler için daha karlı hale getirmek ve böylece topraklarında tutmak için değişiklikler yapmak zorunda kaldılar. İşü̈cü yetersizliği ücretlerin artmasına bu ise yaşam standardının yükselmesine neden olmuştur. Gelirin artması özellikle kentsel alanda üretilen ürünlerde ve lüks tüketimde artışa yol açmıştır (Decameron, 2014).

Veba Avrupa'nın sosyal ve ekonomik yapısını büyük ölçüde geri dönülemez bir şekilde değiştirdi. Yaşanan kitlesel ölümler, Avrupa altın ve gümüş para arzının kişi başı bazında artmasını 
sağladı ve bu durum İngiltere'de 1370 'lerin ortalarına kadar düşüş göstermeyen enflasyonun ortaya çıkmasına neden olmuştur (Aberth, 2010, s.203).

\section{Yeni Dünya Çiçek Salgını (1520 )}

Çiçek hastalığının dünya tarihi üzerinde oldukça önemli etkileri vardır. 18. yüzyıl boyunca Avrupa genelinde iktidarda olan beş hükümdarda dahil her y1l 400.000 kişinin ölmesine neden olmuştur. (Riedel, 2005, s.21). Kolomb ve devamındaki kaşiflerin 1492'de Yeni Dünyayı keşfetmeleri birçok etkileşimi de beraberinde getirmiştir. Avrupalılar daha önce bilmedikleri yeni ürünle tanışırken yeni kıtada tedavisini bilmedikleri yeni hastalıklarla da (kızamık ve çiçek başta olmak üzere) tanışmışlardır. $\mathrm{Bu}$ hastalıkların yerli halk üzerinde yıkıcı etkileri olmuştur. Çiçek hastalığının Kuzey Amerika yerlilerinin üçte birinden fazlasını öldürdüğü tahmin edilmektedir (Matillano,2011:3). Meksika'da ise Avrupa'dan gelen hastalıklardan dolayı nüfusun 1519-1620 arasında 28 milyondan 1,6 milyona düştüğü tahmin edilmektedir (Bell ve Maureen, 2004, s.6). Dünya'da yaklaşık olarak 500 milyon kişinin çiçek hastalığından dolayı ölmüş olabileceği tahmin edilmektedir. Hastalıkla ilgili yapılan çalışmalar sonucu 8 Mayıs 1980 tarihinde, Dünya Sağlık Örgütü çiçek hastalığının dünya çapında ortadan kaldırıldığını onaylamıştır (Tognotti, 2010, s.264).

İspanyolların Amerika'ya ulaşmasından sonra yerlilerle aralarındaki sorun askeri müdahaleye dönüştü. Çiçek ve diğer hastalıklara bağışıklığı olmayan yerlilerin savaştan çok hastalıktan ölmesi sonucu olarak bu yeni topraklar Portekiz, İspanya, İngiltere, Danimarka, Fransa, İsveç ve Hollanda tarafından kolonileştirildi. Avrupa'da 1500-1800 yılları arasında hâkim ekonomik görüş olan Merkantilizmin temel felsefesi devletin dış ticarete müdahalesi ile ihracatın artırılması ithalatın azaltılmasını sağlamaktı. Yeni toprakların keşfiyle başlayan kolonileşme bu amaca en iyi şekilde hizmet etmekteydi.

Yine merkantilist düşünceye göre zenginliğin kaynağı sayılan altın ve gümüşte yeni keşfedilen yerlerden bol miktarda Avrupa'ya getirilmiştir. 15.yüzy1lda Avrupa'da altın az bulunuyordu ve para kıtlığı vardı. Ayrıca Avrupa'da aristokratların ve sanayinin talep ettiği birçok ürün ithal edilerek karşılanmaktaydı ki bunun için de altına ihtiyaç duyulmaktaydı. Bu talebin giderilmesinde yeni keşfedilen kıta önemli bir rol oynadı. Çiçek salgını ve diğer salgınlarında etkisiyle neredeyse hiç askeri müdahale olmadan çok büyük miktarlarda altın Avrupa’ya aktarılmıştır (Dura, 2011).

\section{İtalyan Vebasi (1629-1631)}

Vebanın İtalya'ya da ortaya çıkmasında ki temel etken 1618 ile 1648 yılları arasındaki Otuz Yıl Savaşı'nda hastalığı taşıyan Alman ve Fransız askerlerinin İtalya'ya gelmesidir. Hastalık alınan tedbirlere rağmen kısa sürede Milano'ya kadar yayıldı. Bu arada liman ticareti durdurularak yabanciların kente girmesi yasaklandı. Fakat alınan tüm tedbirlere rağmen hastalık yayıldı ve şehir nüfusunun büyük bir kısmını etkileyerek ölüm sayısını artırdı. (Alfani, 2011, s.20). İtalya'nın önemli şehirlerindeki kayıplar aşağıdaki tabloda gösterilmiştir.

Tablo 2: İtalyan Kentleri ve Ölüm Oranları

\begin{tabular}{|l|c|c|c|}
\hline \multicolumn{1}{|c|}{ Kent } & Nüfus (1630 yılı) & Ölüm tahminleri (1631) & Nüfus kaybı \% \\
\hline Verona & 54.000 & 33.000 & $\% 61$ \\
\hline Milan & 130.000 & 60.000 & $\% 46$ \\
\hline Venedik & 140.000 & 46.000 & $\% 33$ \\
\hline Floransa & 76.000 & 9.000 & $\% 12$ \\
\hline
\end{tabular}

Kaynak: https://tr.qwe.wiki/wiki/1629\%E2\%80\%9331_Italian_plague

İtalyan vebası sonrası İtalyan şehir devletleri güçlerini kaybetmeye başladı. Akdeniz’de önemli bir ticaret filosuna sahip olan Venedik Cumhuriyeti salgınla birlikte nüfusunun büyük bölümünü ve 
ticari gücünü kaybetmiştir. Benzer şekilde 16. ve 17. yy da Avrupa'nın finans merkezi haline gelmiş olan Ceneviz Cumhuriyeti'nde salgından etkilenerek gücünü kaybetmiştir (EB, 2020).

Vebanın İtalya'daki ekonomik etkileri daha çok şehir devletleri üzerinde yoğunlaşmıştır. Salgının ekonomik etkileri; azalan nüfusla birlikte işgücü arzının düşmesi, yaşam standartlarında artış ve uzun dönemde büyümeye bağlı olarak ücretlerdeki artış şeklindedir. İtalya'nın gelişmiş bölgelerindeki şehirlerin nüfusundaki azalma vebanın potansiyel olarak ekonomik bölgelerin veya tüm ülkelerin gerilemesine neden olmuştur (Alfani, 2016, s.1).

Şekil 1: İtalya'da salgının etkilediği şehirler.

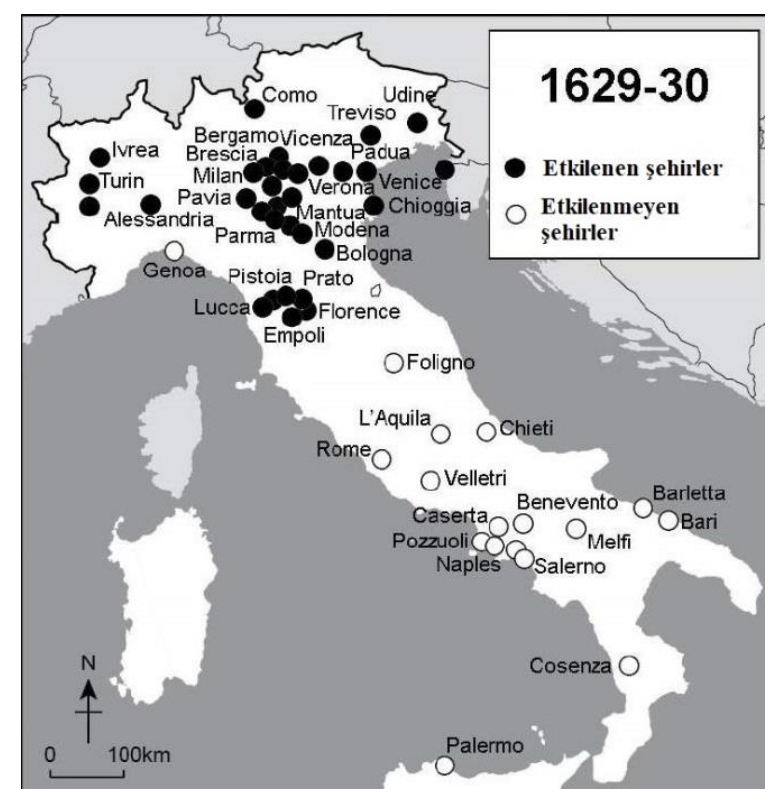

Kaynak: Alfani, 2016:4

Haritadan da görüleceği üzere salgın İtalya'nın kuzeyini daha çok etkilemiştir. Bu bölgelerin yüksek nüfuslu ve sanayi bölgesi olması salgın sonrası şehir yapısını da etkileyen nedenlerdendir. Mahalleler birleşmiş ve özellikle Milano da mekânsal ayrımcılık görülmüştür. Bir diğer sosyal etkide sosyal etkileşimin salgın sonrası yoğunlaşmasıdır.

\section{Londra Büyük Vebası (1665-1666)}

1665'ten 1666'ya kadar süren Büyük Veba, İngiltere'de ortaya çıan ve Londra nüfusunun yaklaşık dörtte birinin (100.000) öldüğü önemli salgınlardan biridir. Hastalık Londra'nın batısında yer alan fakirlerin yaşadığı ve hijyen şartlarının çok kötü olduğu St Giles-in-the-Field'da başlamıştır. Kötü koşullar nedeniyle bölgede sürekli salgın hastalıklar görülmekteydi (Fathers, 2020). Bu etkenler salgının fakir bölgelerden şehre yayılmasını hızlandırmıştır.

Salgının Londra'daki ilk etkisi şehrin yeniden imarı konusunda oldu. Londra yangınıyla birlikte şehir yeniden imar edildi, sokaklar daha geniş hale getirilirken açık kanalizasyonlar kapatıldı. 1665'e gelindiğinde Londra İngiltere'nin ekonomik gücünü yansıtmaktaydı. Sömürgelerden gelen ürünler ve uzak ülkelerle yapılan ticaret ülkeye ve bölgeye zenginlik getirmişti. Salgın dönemi ve sonrasında halk sağlığ finansmanı için ayrılan fonların kilise cemaatlerine kullandırılması yoksulları etkilemiştir. Bu fonların kullanımında fakirlerden çok zenginler yararlanmaktaydı (Fischer,2017:51-53). Bununla birlikte büyük veba, İngiltere'nin denizaşırı ticaretini kötüleştirmiş ve 1603 ve 1625 yıllarında başkentin ticaretini ciddi şekilde azaltmıştır (Bean ve William, 1963, s.433-434).

\section{Kolera Pandemileri 1-6 (1817-1923)}

İlk Asya kolera salgını veya Asya kolerası olarak da bilinen ilk kolera salgını (1817-1923), Kalküta şehrinin yakınında başladı ve Güneydoğu Asya'da Orta Doğu, Doğu Afrika ve Akdeniz kıyılarına yayıldı. Bu ilk salgın, Asya'daki hemen hemen her ülkeyi etkileyen benzeri görülmemiş geniş bir bölgeye yayıldı (CBC, 2010). Kolera epidemik bir hastalık olarak Hindistan'ın bazı bölgelerinde bulunurken 1817 'de Hindistan'ın diğer bölgelerine ve buradan da dünyaya salgın bir hastalık olarak 
yayılmıştır. Ticaret vasıtasıyla yayıldığı yerlerde milyonlarca insanın ölümüne neden olmuştur. Hastalık 1817-1823, 1826-1837, 1847-1862, 1864-1875, 1883-1892 ve 1899-1923yılları arasında altı büyük pandemi olarak etkili olmuştur (Uzluk, 1948, s.8-9).

İkinci salgın Hindistan'da başladı ve 1830 'da Finlandiya, Polonya'ya ve Rusya'da görüldü. Yoksulluktan ve patates kıtlı̆̆ından kaçan İrlandalı göçmenler hastalığı Avrupa'dan Kuzey Amerika'ya sonrasında da 1833 'te Latin Amerika'ya yayıldı. Genellikle en ölümcül olarak kabul edilen üçüncü pandemi, bir kez daha Hindistan'da ortaya çıkarak Asya, Avrupa, Kuzey Amerika ve Afrika'da büyük kitlesel ölümlere neden oldu (CBC, 2010).

Kolera yüzyıllar boyunca, ticaret gemileri tarafindan ve Orta Doğu'da Mekke'ye giden hacılar tarafından ara sıra görünümlerle Hint yarımadasının nehir bölgelerine hapsedilmişti. Ancak büyük oranda yayılması ise emperyalizm, ticaret, askeri çatışma ve göç (özellikle köle ticareti) yoluyla olmuş ve sanayileşmeyle birlikte hastalığın yayılma hızı artmıştır. Hastalığın nedeni anlaşılıncaya kadar ülkeler sağlık sisteminde çok büyük değişiklikler yapmamışlardır. Robert Koch'un koleranın nedenini bulmasından sonra sosyal refah sistemi ile desteklenmiş bir sağlık altyapısı oluşturulmaya başlanmıştır. Ayrıca bulaşıcı hastalıkların önlenmesi amacıyla uluslararası kuruluşlarda ortaya çıkmaya başlamıştır (Lee ve Dodgson, 2000, s.217-220).

\section{Üçüncü Veba Salgını (1885 )}

Üçüncü veba salgını, 1855 yılında Qing hanedanının Xianfeng İmparatoru'nun beşinci yılında Çin'in Yunnan kentinde başlayan büyük bir bubonik salgın pandemisiydi. Bubonik veba olayı tüm yerleşik kıtalara yayılarak Hindistan ve Çin'de 12 milyondan fazla ölüme yol açtı (Stenseth,2008:774). Hastalığın Çin'den yayılması büyük kıyı nakliye merkezleri olan Hong Kong ve Guangzhou şehirlerinden olmuş ve bu yolla tüm dünyaya yayılmıştır. (Sanburn, 2010).

Hindistan'da hastalığın etkilerini gidermek için uygulanan karantina ve baskıcı tutumlar yerel halkın İngiliz hükümetine karşı olan tutumunda değişmeye neden olurken alınan sağlık önlemlerine halkın tepkisi, nihayetinde ülkedeki tıbbi müdahalenin politik kısıtlamalarını ortaya çıkardı. Deneyimler Hindistan'ın modern halk sağlığ hizmetlerinin gelişiminde etkili olmuştur.

Salgının Çin üzerinde yarattı̆̆ etkilerden biri insanların göç etme zorunda olmaları ve bunun sonucunda tarımsal üretimde ciddi azalmaların yaşanmasıdır. Tarımsal ürünlerin yokluğunun getirdiği sorunların yanı sıra Çin'in bazı bölgeleri için önemli bir ticari ürün olan pamuk ekimi ve hasadı da salgından ciddi bir şekilde etkilenmiştir.

\section{Sarı Humma Salgını (1800'lerin Sonu)}

Bu viral enfeksiyon Güney Amerika ve Sahra altı Afrika için endemiktir. Sarı humma 1700 ve 1800'lerde Amerika'daki en korkulan hastalıklardan biri olmuş ve ülkedeki son salgın 1905 'te sona ermiştir. 1793'te sarı humma, ülkenin başkenti olan Philadelphia' da nüfusun yaklaşık yüzde 10'unun ölümüne neden olurken salgının şehirde yayılması üzerine Başkan George Washington ve Dışişleri Bakanı Thomas Jefferson, şehir dışına çıkmış ve sonuçta Washington şehri ülkenin yeni başkenti olmuştur. Hastalığın bu kadar etkili olmasının temel nedeni hastalığın nasıl yayıldığıyla ilgili bilginin olmamasiydı (Rosenwald, 2020). 
Şekil 2: Amerika'da salgının etkilediği şehirler.

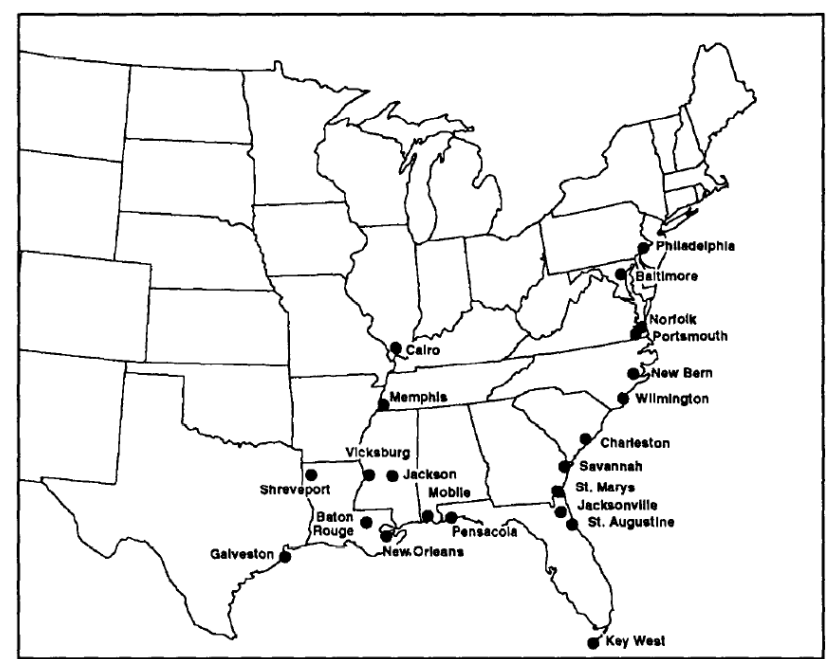

Kaynak: Patterson, 1992:863

1800'lerin ilk çeyreğine kadar fazla etkisi olmayan hastalık Amerika'nın güney kesimlerinde görülmekteydi. Meksika körfezine kıyısı olan ve önemli bir ticaret kenti New Orleans'ta hastalığın görülmesinden kısa bir süre sonra salgın 1850 'de tüm ülkeye yayıldı. Hastalık yoğun olarak ticaret yapılan limanlarda ve balıkçı kasabalarında görülmüş ve salgının yayılmasında kötü uygulanan karantina şartları yanında iç savaşta etkili olmuştur. Sarı hummanın sıklıkla yabancı hastalığı olarak adlandırılmasının nedeni ülkeye gelen yabancılar özellikle büyük kıtlıktan kaçan İrlandalılardan kaynaklandığı istatistiki bilgilere göre belirtilmiştir (Patterson, 1992, s.857-860).

Amerika'daki salgının ekonomik maliyetlerini hesaplamak çok kolay olmamakla birlikte 18461850 arasında New Orleans'ta salgın hastalık için 45 milyon dolar harcama dişında emek kaybı, ticaretteki azalma ve göç bölgeyi ciddi bir şekilde etkilemiştir. Ticaret ve nüfus kayıplarının etkisi ancak beş yılda giderilebilmiştir (Stepan, 1978, s.403). Memphis'te ise nüfusun büyük bölümü salgından etkilenirken yerel işletmelerin kayb1 100 milyon doları, Misisipi vadisindeki toplam ticari kayıplar ise 200 milyon dolar olarak gerçekleşmiştir. Sarı hummanın gerçek maliyetlerinin, insani ve ekonomik açıdan doğru bir şekilde ölçülmesi imkânsı olmakla birlikte kentsel ve ticari büyümeyi geciktirmede önemli rol oynamıştır (Patterson, 1992, s.857-864).

\section{Rus Gribi (1889-1890)}

19. yüzyılın son büyük salgını olan “Asya gribi” veya "Rus gribi” olarak ta bilinen 1889-1890 grip salgını, dünya çapında yaklaşık 1 milyon insanın ölümüne neden olmuştur. Hastalı̆̆ın ilk belirtisi Mayıs 1889 'da Rusya'dan başlayarak hızla Aralık 1889'da Kuzey Amerika'ya, Şubat-Nisan 1890'da Güney Amerika'ya, Şubat-Mart 1890'da Hindistan'a ve Mart-Nisan 1890'da Avustralya'ya yayılmıştır (Garmaroudi, 2007).

1889 gribi sadece dört ay gibi kısa bir sürede yayılmış ve bu açıdan bakıldığında ise ekonomik ve sosyal etkilerinin tam olarak tespit edilmesi zorlaşmıştır. 1889-1890 Rus Grip salgınını 1890 ve 1891'de salgının da etkili olduğu ekonomik durgunluk izlemiştir (Mitchener ve Weidenmier, 2007, s.463).

\section{İspanyol Gribi (1918-1920)}

H1N1 grip virüsünden kaynaklı İspanyol gribi, I. Dünya Savaşı'nın son dönemlerinde yayılarak yaklaşık 50 milyon insanın ölümüne neden oldu. Bu rakam neredeyse 1.Dünya Savaşında ölenlerin iki katından fazlaydı. 1918 yılı başlarında askeri kamplarda tespit edilen ve çok sayıda askere bulaşan bu virüs, Birinci Dünya Savaşı'nın sonunda askerler eve döndükçe hızla yayıldı. Savaş zamanı sırasında sansür ve propaganda nedeniyle hastalık hakkında iletişimin büyük ölçüde çarpıtılması vaka sayısının artmasına neden olmuştur. (AEGON, 2020). Ülkeler hastalıkla ilgili haberleri savaş dolayısıyla sansürlerken İspanya'daki grip vakaları açık olarak haber yapılmış ve bundan dolayı da salgın daha sonra İspanyol gribi olarak adlandırılmıştır. Salgın üç dalga halinde yayılmıştır. 
Grafik 1: 1918 İspanyol gribi (1000 kişiye düşen ölüm sayısı)

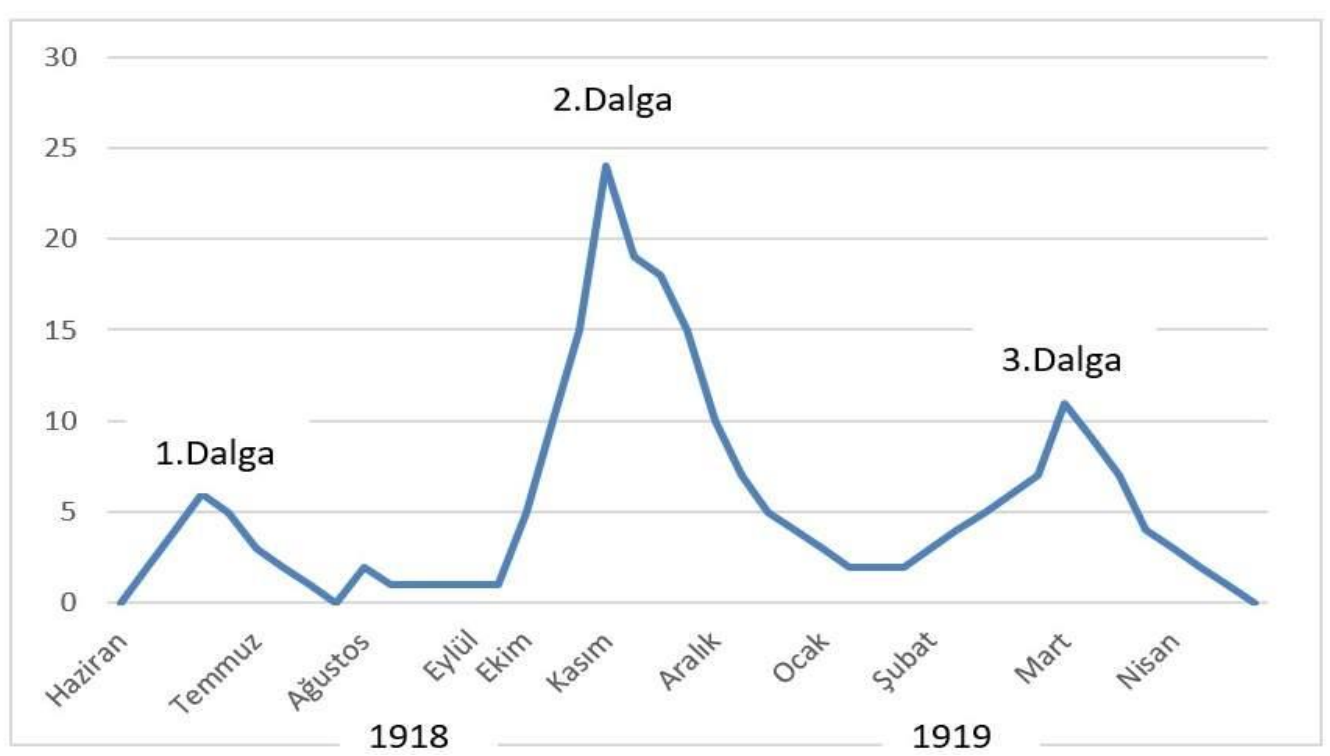

Kaynak: https://www.the-sun.com/news/713379/second-wave-coronavirus-flu-outbreak/

Her salgının toplum üzerinde farklı ekonomik ve sosyal etkileri olmuştur. Salgınlar genellikle yaşlıları, çocukları ve bağışıklık sistemi zayıf olan hastaları etkilerken İspanyol gribi dayanıklı ve tamamen sağlıklı gençleri etkilemiştir. Salgın öncesi dünyada ortalama beklenen ömür 60 civarında iken salgın sonrası bu rakam 50'ye düşmüştür (Roser, 2020, s.2).

Salgının ekonomik etkilerini tespit için İsveç’te yapılan bir çalışmada sermaye gelirlerini \%5\%6 azaldığı yoksulluğun ise \%11 arttığı hesaplanmış olup salgınla ekonomik performans arasında bir ilişkinin olduğu ortaya konmuştur (AEGON, 2020). Salgın Amerika'da gelir kaybına yol açarken Hindistan'da tarım ekonomisi üzerinde etkili olmuş tarımsal üretim salgın döneminde sırasıyla \%8 ve \%3,3 azalmıştır (Bell ve Lewis, 2005, s.16).

\section{Asya Gribi (1957-1958)}

1918 salgınından sonra gribin görülme sıklığı ve etkisindeki azalma kullanılan ilaçlarla birlikte tekrar görülmeyeceği düşünülürken virüsün mutasyona uğrayarak ortaya çıkması yeni bir salgını tetiklemiştir. Asya gribi olarak da bilinen 1957-1958 influenza pandemisi, Guizhou, Çin kaynaklı ve dünya çapında en az 1 milyon insanı öldüren influenza A virüsü alt tipi H2N2'nin küresel bir pandemisiydi (Clark, 2008s. 78-81).

Asya gribinin Amerika ekonomisi üzerinde önemli bir etkisi olmamıştır. Amerikan ekonomisi yaklaşı \%1 benzer şekilde Kanada ekonomisi de \%1,2 azalmıştır (Henderson vd., 2009, s.270). Asya gribinin Amerika'da görülmesinden sonra S\&P 500 \%20,7 düşüş yaşamıştır ve 1958 resesyonunun nedeni olarak gösterilmiştir. Önceki salgınlarda olduğu gibi bu salgında da işgücü etkilenmiştir. Dünya genelinde işgücü büyüme oranları salgın öncesine göre azalma kaydetmiş ve işgücü büyüme hızı yanında işsizlik oranları da birçok gelişmiş ekonomide artmıştır (UN, 1960, s.26).

Tablo 3: İşgücü Büyüme Hızı ve İşsizlik Oranları

\begin{tabular}{|c|c|c|c|c|c|l|c|c|c|c|c|}
\hline & \multicolumn{3}{|c|}{$\begin{array}{c}\text { İşücü Büyüme } \\
\text { Hızları }\end{array}$} & \multicolumn{3}{|c|}{ İşsizlik Oranları } & & \multicolumn{3}{c|}{$\begin{array}{c}\text { İşgücü Büyüme } \\
\text { Hızları }\end{array}$} & \multicolumn{3}{c|}{ İşsizlik Oranları } \\
\hline & $\mathbf{1 9 5 0 - 5 5}$ & $\mathbf{1 9 5 7 - 1 9 5 8}$ & $\mathbf{1 9 5 7}$ & $\mathbf{1 9 5 8}$ & $\mathbf{1 9 5 9}$ & & $\mathbf{1 9 5 0 - 5 5}$ & $\mathbf{1 9 5 7 - 1 9 5 8}$ & $\mathbf{1 9 5 7}$ & $\mathbf{1 9 5 8}$ & $\mathbf{1 9 5 9}$ \\
\hline Japonya & 7,9 & 2,4 & 3,1 & 3,9 & 3,4 & ABD & 3,3 & 1 & 4,3 & 6,8 & 5,5 \\
\hline Almanya & 7,4 & 2,1 & 3,4 & 3,5 & 2,4 & Norvec & 3 & 0,4 & 1,4 & 2,3 & 2,2 \\
\hline
\end{tabular}




\begin{tabular}{|l|c|c|c|c|c|l|l|l|l|l|l|}
\hline İtalya & 5,5 & 1 & 9 & 9 & 8,7 & Belçika & 2,9 & 0,3 & 3,8 & 5,2 & 5,9 \\
\hline Hollanda & 4,5 & 1,2 & 1,3 & 2,4 & 1,9 & İsveç & 2,9 & 0,4 & 1,9 & 2,5 & 2 \\
\hline Fransa & 4,3 & 0,6 & 0,8 & 0,9 & 1,7 & Danimarka & 2,3 & 0,4 & 10,2 & 9,6 & 6,1 \\
\hline Kanada & 4 & 2,2 & 4,3 & 6,6 & 5,6 & İngiltere & 2,2 & 0,9 & 1,6 & 2,2 & 2,2 \\
\hline
\end{tabular}

Kaynak: UN, 1960, s.26

Asya krizinin diğer krizlerden en önemli farkı genç nüfusun etkilenmesidir. Bu durum işgücünü olumsuz olarak etkileyerek tarımsal ürünlerin verimini de düşürmüştür. Salgın öncesi dönem ile salgın sonrasında ülkelerin tarımsal ürün verimliliğinde ciddi azalmalar görülmüștür. Bunun temel nedeni ise azalan işgücünden dolayı işgücü başına düşen üretimin artmamasıdır (UN, 1960, s.27).

Tablo 4: Tarımsal ürün üretimi \%

\begin{tabular}{|l|c|c|}
\hline & $\mathbf{1 9 5 0}$ & $\mathbf{1 9 5 8}$ \\
\hline Kanada & 13,2 & 7,3 \\
\hline Danimarka & 21,3 & 17,5 \\
\hline Almanya & 10,9 & 8,6 \\
\hline Fransa & 16,2 & - \\
\hline İtalya & 29,3 & 20,8 \\
\hline Japonya & 26 & 18,4 \\
\hline Hollanda & 14,2 & 11,2 \\
\hline Norveç & 14,9 & 11,8 \\
\hline İngiltere & 6 & 4,4 \\
\hline ABD & 7,8 & 5,5 \\
\hline
\end{tabular}

Kaynak: UN, 1960, s.27

\section{Hong Kong Gribi (1957-1958)}

Hong Kong gribi , 1968 ve 1969 y1lında görülen ve dünya çapında tahmini bir milyon insanın ölümüne neden olan grip salgınıdı (CDC, 2019). Hong Kong'daki salgının ilk kaydı 13 Temmuz 1968'de ortaya çıktı. Temmuz 1968 'in sonunda Vietnam ve Singapur'da geniş çaplı salgınlar bildirildi. Eylül 1968 'de Hindistan, Filipinler, Kuzey Avustralya ve Avrupa'ya sonrasinda virüs Kaliforniya'da Vietnam Savaşı birliklerinin geri dönmesiyle yaygınlık gösterdi (SB, 2020). Hong Kong gribinin ekonomik etkileri üzerine Amerika ve Kanada için yapılan çalışmalarda bu ekonomileri çok etkilemediği sonucuna ulaşılmıştır. Okul ve işyerinde devamsızlık nedeniyle bazı toplumsal aksaklıklar oluşmuş, ancak bu çoğunlukla çocuklar, okul öğretmenleri ve sağlık çalışanları arasında yoğunlaşmıştı. Pandemi tepe noktasında iken ABD'de iş devamsızlığ \%3-\%8 arasındaydı. Ekonomik etkisi küçüktü ve ABD'deki GSYİH'yi yaklaş1k \%1 düşürmüştür. (Saunders vd., 2016, s.8). 
Grafik 2: GSMH Büyüme Oranları (1967-1970 \%)

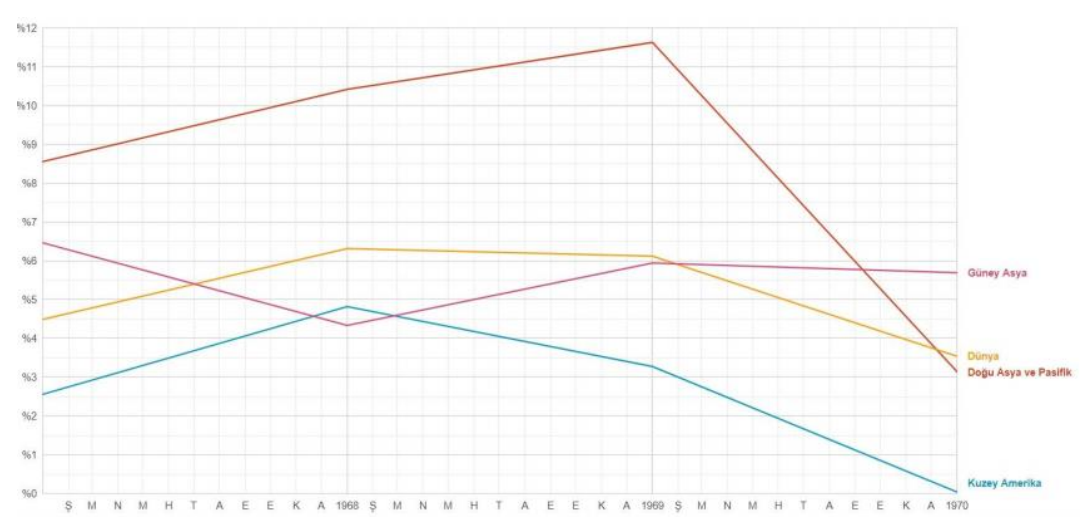

Kaynak: World Bank, https://www.worldbank.org/

\section{Yakın Dönemde Yaşanan Pandemiler}

Yakın dönem salgınlar 1980 sonra görülen salgınları ifade etmektedir. Bu çerçevede görülen önemli salgınlar HIV/AIDS (1981-), SARS (2002-2004), Domuz Gribi (2009-2010), EBOLA (20142016), MERS (2015- ) şekilde siralanabilir.

\section{HIV/AIDS (1981-)}

Bu salgınlardan ilki olan HIV ilk tanımlaması yapıldığından günümüze kadar küresel ölçekte üzerine odaklanılmış ve çalışmaları yapılan bir hastalıktır. 1981 yılında edinilmiş ilk immün yetmezlik sendromu (AIDS) vakaları bildirilmesinden sonra pandemik oranlara ulaşmış ve tahmini 65 milyon enfeksiyon ve 25 milyon ölümle sonuçlanmıştır (Cohen vd., 2008, s.1244).

HIV'ın ekonomik etkileri her ülkede görülmekle birlikle özellikle Afrika ülkelerindeki etkisi daha ağır olmaktadır. Haftalığın birçok makroekonomik etkisi vardır. Özellikle hastalıkla mücadelede kullanılan ilaçların üretimi ve kimlerin bu ilaçları kullanacağına karar verilmesi önemli bir sorundur.

HIV'ın Afrika'da ekonomik gelişme üzerinden önemli etkisi, kilit sektörlerdeki nitelikli işgücü kaybına da yol açmasıdır. Ülke ekonomileri üzerindeki bir diğer etkisi de sağlık harcamalarında yarattığı arttıştır. 1990 ve 2017 arasında, sağlık için kalkınma yardımı \%394,7 artarken, 2017 yılında 9,1 milyar dolar HIV/AIDS'i hedefleyen sağlık için 37,4 milyar dolarlık kalkınma yardımı ödenmiştir. 2000-2015 yılları arasında dünya çapında HIV/AIDS için 562,6 milyar dolar harcanırken hükümetler bu toplam harcamanın \%57,6'sını finanse ettiler. Küresel HIV/AIDS harcamalar1 2013 yılında 49,7 milyar seviyesine ulaşarak 2015 yılında 48,9 milyar dolara geriledi. 2015 y1lında 9,3 milyar dolar finansman HIV/AIDS önleme için ve 27,3 milyar dolar ise bakım ve tedaviye ayrılmıştır (Dielman, 2018, s.1799).

\section{SARS (2002-2004)}

Şiddetli akut solunum sendromu (SARS), ise bir Covid-19'ün neden olduğu viral bir solunum hastalığıdır. Salgın ilk olarak 16 Kasım 2002'de Guangdong, Çin'deki Foshan'da tespit edildi. Hastalık, küresel salgın haline gelmeden önce Kuzey Amerika, Güney Amerika, Avrupa ve Asya'da birçok ülkeye yayıldı. Dünya Sağlık Örgütü'ne (WHO) göre, 2003 salgını sırasında dünya genelinde toplam 8.098 kişi SARS hastalığından etkilenirken bunlardan 774 kişi ölmüştür (CDC, 2004, s.2).

SARS'ın ekonomik etkileri diğer salgınlardan farklı bir boyutta incelenmiştir. Asya ülkeleri için yapılan çalışmalar SARS'ın daha çok, turizm ve perakende hizmet sektörü gibi endüstrilerdeki zararlarını değerlendirmeye odaklanmaktadır. Bununla birlikte uluslararası ticaretin artmasından dolayı SARS'ın ekonomik etkileri birçok ülkeyi etkiledi. Bir ülkede yaşanan herhangi bir ekonomik şokun, küreselleşmeyle ilişkili artan ticaret ve finansal bağlantılar yoluyla diğer ülkelere hızla yayılması mümkün olmuştur. Dünya daha entegre hale geldikçe, SARS gibi bulaşıcı bir hastalığın küresel maliyeti artış gösterecektir (Wha ve McKibbin, 2004, s.92-93). 
Grafik 3: Çin'in Perakende Satışları

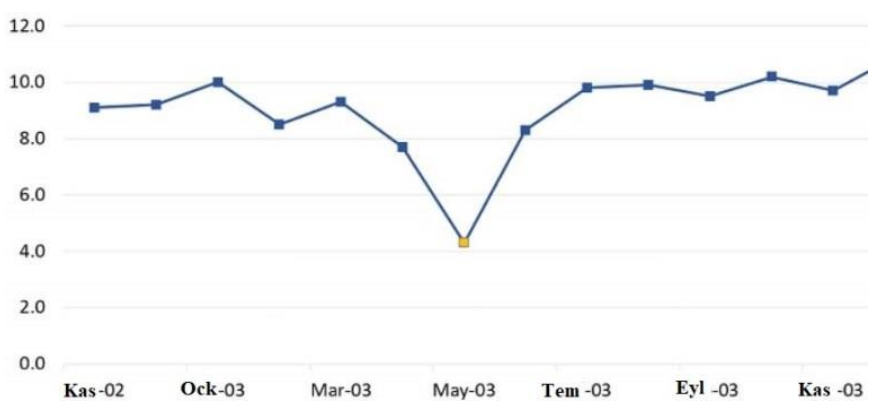

Kaynak: CNBC, https://www.cnbc.com/2020/02/11/coronavirus-4-charts-show-how-sars-hit-chinas-economy-in-2003.html

2002-2004 yılları arasında SARS salgını Çin ve Hong Kong ekonomilerini ciddi olarak etkiledi. Bununda etkisiyle küresel ekonominin kaybı yaklaşık 40 milyar dolar oldu. (Küçükşehir,2020). SARS salgını, Çin'in ekonomik büyümesinin 2003 yılının ilk çeyreğinde yıllık \%11,1'den sonraki üç ayda $\% 9,1$ 'e düşmesine neden olurken SARS'ın 2002-2004 y1lları arasında küresel ekonomiye 30 ila 50 milyar dolar arasında bir maliyeti yüklediği tahmin ediliyor (Kessler,2020). Turizm sektöründeki olumsuzluklar eğlence sektörünü de etkilemiş, Amerika'nın en büyük eğlence firması Park Place Entertainment'ın gelirleri \%50 azalmıştır. Dünyanın en büyük sigorta şirketlerinden AIG'nin Çin'deki gelirleri \%30 oranında düşüş kaydetmiştir. Dünya genelinde ekonomik yavaşlama sonucu Asya'da petrol talebi günde 300.000 varil düşerek, Kuveyt'ten Venezuela'ya petrol şirketlerinin gelirlerini düşürmüştür. (Begley, 2013).

\section{H1N1 Domuz Gribi (2009-2010)}

1980 sonrası dönemde görülen bir diğer salgında H1N1-domuz gribidir. 10 Ağustos 2010 tarihinde, Dünya Sağlık Örgütü (WHO) domuz gribi salgınının resmi olarak bittiğini ilan etmes domuz gribinin tamamen ortadan kalktığı anlamına gelmez. Pandemiye neden olan H1N1 virüsü dünya çapında mevsimsel olarak dolaşmaya devam eden bir grip türüdür. Domuz gribinin beklenen ekonomik etkileri önceki salgınlarla benzer şekildedir. Önceki pandemilerde de görüldüğü üzere ekonomik aktivitelerin azalmasının nedeni ölümler ya da işten uzaklaştırmalar değil güven kaybı ve korku kaynaklı harcama modellerindeki değişikliğin piyasaları bozması olarak görülmüştür (McKibben, 2009).

Kuzey Amerika'dan sonra influenza H1N1 salgınının dünya çapında en çok etkilediği bölge, Güney Amerika bölgesidir. Genellikle domuz gribi olarak adlandırılan bu hastalık kış aylarında halk sağlığı ve ekonomi açısından Güney Koni ülkelerinde (Arjantin, Şili, Paraguay ve Uruguay) özellikle yüksek bir etkiye sahiptir. Pandeminin büyüme hızları üzerindeki etkinin büyüklüğünü tam olarak hesaplamak zor olmakla birlikte, ekonomik kayıp tahminleri, etkilenen ülkelerde GSYİH'nın \%0,5'i ila \%1,5'i arasında değişmektedir (The Economist, 2009).

Kore ekonomisi için yapılan bir çalışmada 2009 salgını H1N1 influenza için tahmini yıllık sosyoekonomik maliyetler, Kore GSYİH'sının \%0,14'ünü aşmış ve 1.090 milyar ABD Doları olarak tahmin edilmiştir. Dolaylı maliyetler dahil edildiğinde toplum üzerinde beklenenden daha büyük bir yükle sonuçlanabileceğini göstermektedir. Bu nedenle, salgınların toplum üzerindeki etkisini azaltmak için bu tür bir salgında kapsamlı önleme ve kontrol politikalarına ihtiyaç duyulacaktır (Kim vd., 2013, s.395).

\section{EBOLA (2014-2016)}

Domuz gribinden sonra görülen Ebola virüsü ilk olarak 1976'da Ebola Nehri yakınında şimdi Demokratik Kongo Cumhuriyeti'nde tanımlanmıştır. O zamandan beri, virüs periyodik olarak ortaya çıkmakta ve çeşitli Afrika ülkelerindeki insanları enfekte etmektedir (CDC,2019). Ebola virüsü hastalığı $(\mathrm{EVH})$, öncelikle Afrika kıtasında meydana gelen nadiren ortaya çıkan, insanları ve diğer primatları etkileyen ciddi, genellikle ölümcül bir hastalıktır. Ortalama EVH vakası ölüm oranı \%50 civarındadır. Virüs insanlara vahşi hayvanlardan geçer ve insandan insana bulaşmaktadır (Sağlık Bakanlığı, 2020).

2014'teki Ebola salgın, etkilediği ülkelerde hane halkı gelirlerinin azalmasına ve yoksulluğun artmasına neden olmuştur. Dünya Bankası'nın güncellenmiş 2016 raporunda, Ebola salgınının Liberya, Gine ve Sierra Leone üzerindeki genel etkisinin 2,8 milyar dolar olduğu belirtilmiştir. Ebola ekonomiyi 
çeşitli şekillerde etkilemektedir. Salgınla ilgili ülke çalışmalarına göre Sierra Leone'de özel sektör işgücü kayb1 \%50 olarak gerçekleşmiştir. 2015 yılında Gine, Liberya ve Sierra Leone'de GSYİH 2,2 milyar dolar azaldı ve bu etki sadece makroekonomik istikrarı değil, aynı zamanda gıda güvenliğini, beşerî sermaye gelişimini ve özel sektör büyümesini de tehdit etmiştir (CDC, 2014).

Grafik 4: GSYIH Büyüme Oranları (Sierra Leone, Liberya, Gine)

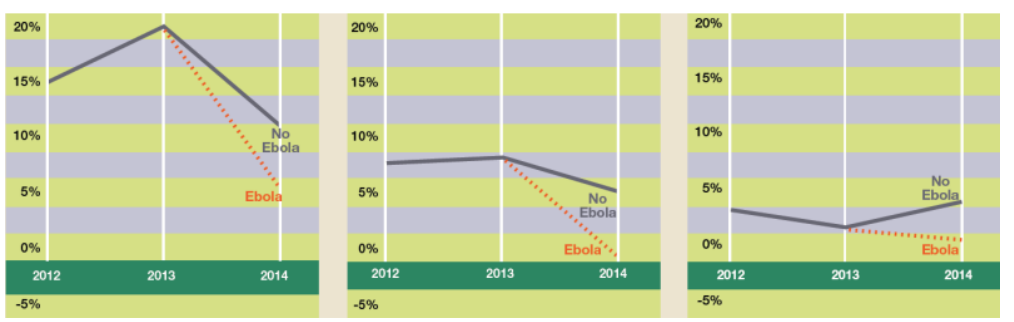

Kaynak: https://www.cdc.gov/vhf/ebola/pdf/impact-ebola-economy.pdf

Ebola salgınının sağlık sektörü üzerine etkine bakıldığında Batı Afrika'da 881 doktor, ebe ve hemşire enfekte olmuş bunların 513'ü eboladan ölmüştür. Eboladan dolayı sağlık iş gücünde. Liberya'da $\% 8$, Sierra Leone'de ise sağlık hizmet sunumunda \%23 azalma olmuştur. 17.300 çocuk bir veya iki ebeveyni ebola salgınından dolayı kaybetmiş aynı zamanda da okul kapanmaları nedeniyle 33 haftadan fazla eğitim sekteye uğramıştır (CDC, 2014).

Salgının bulaşmasını önlemek amacıyla getirilen ticaret ve nakliye kısıtlamalarının Afrika nüfusunun \%43'ü için gelir kaybı yaratmıştır. Ayrıca turistik amaçlı seyahatlerin azalması ülkelerin turizm gelirlerini de etkilemiştir. Salgın öncesi turizm gelirleri Sahra Altı Afrika ülkelerinin milli gelirlerine 36 milyar dolar (milli gelirin \%2,8) katkı yaptığı düşünüldügünde bu gelirin büyük ölçüde kayıp anlamına gelmektedir. Salgının en yoğun olarak görüldüğü Afrika'da salgın olan bölgelere tarım işçilerinin gitmek istememesi tarımsal üretimi olumsuz etkilenmiş dolayısıyla ana gelir kaynağı tarımsal ürünler olan ülkeler ve çiftçiler gelir kaybetmişlerdir. Ebola salgını, seyahat kısıtlamaları ve işçi kaybı nedeniyle madencilik faaliyetinin azalmasına da yol açmış ve Liberya'daki hareket kısıtlamaları nedeniyle altın ve elmas madenciliği de azalmıştır. Boksit, demir cevheri ve altın fiyatları salgının yoğun görüldügü Afrika ülkelerinde önceki yıllara göre yüzde 30 ila 60 oranında düşmüştür. Ekonomik aktivitelerin azalması vergi ve tarifelerden elde edilen geliri de düşürmüştür. Salgının toplam ekonomik ve toplumsal maliyetlerinin 53 milyar dolar olduğu tahmin edilmektedir (MercyCorps, 2019).

\section{MERS (2015- )}

Covid-19 öncesi görülen salgın 2015 yılındaki MERS salgın hastalığıdır. 2012 yılının haziran ayında, Suudi Arabistan'da kaybedilen bir viral pnömoni olgusunda yeni bir koronavirus tespit edildiği bildirildi. Kısa sürede Arap Yarımadası'nda ortaya çıkan bu gizemli ve ölümcül viral pnömoni salgınından sorumlu olan bu yeni Covid-19'e (MERS-CoV) adı verildiği açıklandı (İnal, 2016, s.38).

Suudi Arabistan Krallığının bildirilen en fazla sayıda MERS-CoV hastasına sahip olması ve Krallığın Hacca ev sahipliği yapması nedeniyle Haccın küresel bir salgına neden olma potansiyeli büyük bir endişe kaynağı olmuştur (Al-Tawfiq vd., 2014, s.424). MERS vakalarının tamamı Arap Yarımadası kaynaklı ve hastalığa yakalananalar Arap Yarımadasındaki ve yakınındaki ülkelerde seyahat ve ikamet etmekteydi. Arap Yarımadası dışında en çok vaka Kore'de görülmüş ve hastalık Arap Yarımadasından dönen bir turist tarafindan taşınmıştır. MERS her yaş gurubu için aynı düzeyde etkileyici ve bulaşıcıdır.

MERS salgını, Kore için 2,6 milyar ABD doları turizm kaybına karşılık gelen 2,1 milyon yabancı ziyaretçinin azalmasıyla ilişkilendirildi. Yurt dışı ziyaretçilerin azalmasıyla ilişkili olarak konaklama, yiyecek ve içecek hizmeti ve ulaşım sektörlerindeki tahmini kayıplar sırasıyla 542 milyon ABD doları, 359 milyon ABD doları ve 106 milyon ABD doları olarak gerçekleşmiştir. Kayıplar, Haziran ve Temmuz 2015'te konaklama ve yiyecek ve içecek hizmetleri sektörleri ile Haziran 2015'te ulaşım sektörü için beklenenden daha düşük hizmet endeksleri ile gösterilmiştir (Joo vd., 2019, s.1). Genellikle salgın hastalıklardan etkilenen bir diğer sektör de hava taşımacılığıdır. Uluslararası Hava Taşımacıllı̆̆ Birliği (IATA), SARS'nin trafik hacimleri üzerindeki etkisi açısından bugüne kadarki en ciddi salgın olduğunu belirtmiştir. IATA, 2003 yılında salgının Asya-Pasifik havayollarının yıllık olarak 6 milyar ABD dolar gelirini kaybetmesiyle sonuçlandığı belirtilmiştir (Delivorias ve Scholz, 2020, s.4). 


\section{Covid-19 Pandemisi}

Covid-19 ya da diğer ismiyle koronavirüs olan şiddetli akut solunum sendromu 2019 y1lında Çin'de ortaya çıkıp tüm dünyayı etkileyen bir pandemidir. Temmuz 2020 itibarıyla yaklaşık 11 milyon kişiye virüs bulaşmış olup yaklaşık 530 bin kişi hayatını kaybetmiştir. Covid-19 pandemisi, yayıldığ1 bütün ülkelerde sosyal ve ekonomik hayatın olağan dengesini bozmuş, hükümetleri çeşitli önlemler almaya itmiştir. Salgını kontrol altına almak ve kamu sağlığını korumak amacıyla sosyal izolasyon ve kısıtlamalarla okulların kapatılması, seyahatlerin yasaklanması ve esnek veya uzaktan çalışma olanaklarının sağlanması gibi çeşitli müdahaleler hayata geçirilmiştir. Söz konusu uygulamalar insanların günlük yaşam ve çalışma hayatı üzerinde etki yaratırken toplumsal sonuçların yanında insanları ağır ekonomik şartlarla karşı karşıya bırakmıştır.

Yaşanan bu durum dünyanın en büyük ekonomileri de dahil olmak üzere birçok ülkeyi ekonomik durgunluk ve krizle karşı karşıya bırakırken daha önce yaşanan ekonomik krizlerden farklı olarak hem gelişmekte olan ekonomileri hem de gelişmiş ekonomileri etkilemektedir. Pandemi ülkelerin içyapısını olumsuz etkilediği gibi uluslararası para sistemi, uluslararası finans ve ticaret dahil olmak üzere hem gelişmekte olan hem de gelişmiş ülke ekonomiler için kritik önem taşıyan konuları da etkilemektedir.

Kısıtlama sonrası ülkelerin normalleşme sürecine geçişi ile birlikte uzun süredir yavaşlamış olan ekonomiler tekrar açılmaya başlamış olsa da birçok ülke ciddi olarak cari açıklarında ve kamu borçlarında artışla karşı karşıya kalmıştır. 2020 yılı için küresel GSYİH’nın azalacağı ve dünya ticaretinin küçüleceği öngörülmektedir. Ekonomilerin canlanmasına yönelik beklentilerinde olumsuz olması ülkelerin uygulayacağı politikaların ekonomideki tüm aktörlerin (çalışanlar, tüketiciler, firmalar, yatırımcılar ve yerel yetkililer) güvenmediği sürece başarılı olma şansına sahip olmayacağı da açıktır.

Pandeminin ekonomik etkileri önceki pandemilerden çok farklı değildir. Arz ve talep yanlı etkiler salgının ekonomik ve sosyal etki boyutunda birçok olumsuz sonuçlar doğurmasına neden olmaktadır. Salgının kontrol altına alınması için uygulanan sosyal izolasyon ve kısıtlama birçok sektör üzerinde dolaylı ve dolaysız etki yaratmıştır. Bu durum üretimin yavaşlamasına neden olurken gelirler ve dolayısıyla da tüketim ve tasarruflar üzerinde de azaltıcı etki yaratmaktadır.

Krizin arz yönüyle ekonomiye yansımasının işgücü arzı üzerindeki olumsuz etkisi dikkat çekmektedir. Bu etkilerden birincisi, salgınının kendisi doğrudan işgücüne katılımı önemli ölçüde azaltmış olmasıdır. Covid-19 ile enfekte olanlar ile onlarla temasta olan ve tecrit edilen kişiler üretime büyük ölçüde dahil olamamaktadır. İkincisi, kamu sağlığını korumak amacıyla alınan önlemler nedeniyle dolaylı yoldan işgücü arzında azalma görülmesidir. Arz üzerindeki diğer yansıması salgının yayılım hızını azaltmak için yapılan kısıtlamalar ve alınan önlemlerin üretimin azalmasına ve tedarik zincirinin olumsuz etkilenmesine neden olmasıdır (Elgin \& Başbuğ 2020:8). Üretim sürecinde meydana gelen azalma işgücü piyasaları üzerinde de etki yaratarak işsizlik oranlarını artırmaktadır. Covid-19 salgını ile en büyük ekonomilerden olan Amerika Birleşik Devletleri'nde salgının ortaya çıkmasıyla işsizlik maaşına başvuranların sayısı 33 milyonu geçerken ülkede işsizlik oranı, Nisan ayında \%10,3 puan artarak \%14,7'ye yükselmiştir. İşsizlik oran1 1929 yılında yaşanan Büyük Buhran döneminden bu yana en yüksek seviyeye olarak kayda geçmiştir (Euronews, 2020).

Ticari entegrasyonun olduğu bir dönemde bütünleşik piyasalar bu durumdan olumsuz etkilenirken ülkeler arasında ticaretin azalması ülkeye döviz girişini azaltmaktadır. Bu süreçte dış borçları yüksek olan ve yeterli rezervi olmayan ülkeler farklı sorunlarla karşı karşıya kalmaktadırlar. Talep yönüyle bakıldığında ise alınan kamusal ve bireysel önlemler hizmet sektörü üzerinde olumsuz etki yaratmıştır. Okulların uzaktan eğitime geçmesi, sosyal alanların kapatılması, ülkeler ve şehirlerarasında yolculukların kısıtlanması, karantina, sokağa çıkma yasağı, esnek ve uzaktan çalışma olanakları gibi uygulamalar, yaşanan korku ve belirsizlik tüketici davranışları üzerinde olumsuz etki yaratarak harcama eğilimlerini dolayısıyla toplam talebi ciddi bir şekilde etkilemiştir.

Bunların yanında işsizlik oranlarının artması, sokağa çıkma yasakları, yaşlı ve çocukların evde kalması gibi sosyal izolasyon uygulamaları devletlerin yapmış oldukları transfer harcamalarını arttırmaktadır. Ayrıca pandemiyle mücadele kapsamında yapılan sağlı harcamaları da yine kamu harcamalarını arttırmaktadır. Yeterli kaynağa sahip olmayan ülkeler kamu harcamalarının ana kaynağı 
olan vergi gelirlerini arttırma yoluna gitmektedir ki bu uygulamalar başka olumsuzluklara yol açabilmektedir. Yaşanan pandeminin ülke ekonomileri üzerinde birçok olumsuz etkileri bulunmakta ve bu etkiler birbirleri ile etkileşim halindedir.

Ekonomik olarak yeniden canlanma yaşanabilmesi için öncelikle virüsü baskılamak ve halk sağlığı kapasitesini arttırmak için gerekli önlemlerin alınması gerekmektedir. Hükümetlerin normalleşme süreci için ekonominin stratejik konumundaki sektörleri desteklemesi ve mevcut finansal ve ekonomik destek önlemlerinin nasıl uygulanacağını belirtmesi gerekmektedir (Butler, 2020).

\section{Genel Değerlendirme ve Sonuç}

Salgınların ekonomik etkileri tarihsel süreçte ele alınan tüm salgınlarda gözlemlenmiştir. Salgınların ortaya çıktı̆̆ yaşanmıştır. Tarihsel süreçteki salgınlarda her ne kadar yakın dönem salgınlarda olduğu gibi hükümetlerin ve kurumların faaliyetleri gözlemlenmese de hükümet, kurum ve vatandaşlar açısından ekonomik etkileri olmuştur. Yakın dönem salgınlardan kaynaklanan hastalıkların doğrudan ekonomik etkileri, hastalar ve fon sağlayıcılar (örneğin hükümetler, sigortacılar) tarafından artan sağlık harcamalarını ve sağlı çalışanları için artan iş yüklerini içermektedir. Dolaylı etkiler arasında ölümler nedeniyle işgücü kaybı, hastalık ve kısıtlama nedeniyle işgücü verim kaybı sayılabilir. Pandemide, ulusal ve uluslararası seyahatlerin azalması, spor ve diğer etkinliklerde halka açık toplantıların azalması, okulların kapanması virüsün yayılmasını hafifletmeyi amaçlayan uygulamalardandır (Verikios vd., 2011, s.4).

Covid-19 ve SARS için, yatırımcılar ve analistler genellikle en son salgının potansiyel ekonomik etkisini ölçmek için iki virüsü karşılaştırmaktadır. Birçok iktisatçı Covid-19'ün SARS'tan farklı olarak daha fazla enfekte olmasından dolayı Çin ve küresel ekonomiye etkilerinin daha ağır olacağını tahmin etmektedir. SARS Çin'de perakende satışlar yanında endüstriyel üretim, ithalat ve ihracatı da etkilemişti (Lee, 2020).

Yeni Korona virüsün SARS'tan daha fazla ekonomik etkileri olacağına dair başka bir görüşte Çin'in ekonomik durumuyla ilgilidir. 2002'de Çin altıncı büyük ekonomi iken günümüzde ikinci büyük ekonomi konumundadır. Bundan dolayı salgının uzun vadeli ekonomik etkileri Çin'in uygulayacağı politikalarla bağlantılı olacaktır. Uluslararası Para Fonu, 2019 yılında Çin'in küresel ekonomik genişlemenin \%39'unu oluşturacağını tahmin etmektedir. Çin ekonomisi 2003 'te dünya ekonomisinin $\% 4,2$ 'sini oluş̧ururken günümüzde \%16,3'ünü oluşturduğundan dolayı Çin'deki bir yavaşlama dünya ekonomisini daha fazla etkileyecektir (Feuer, 2020).

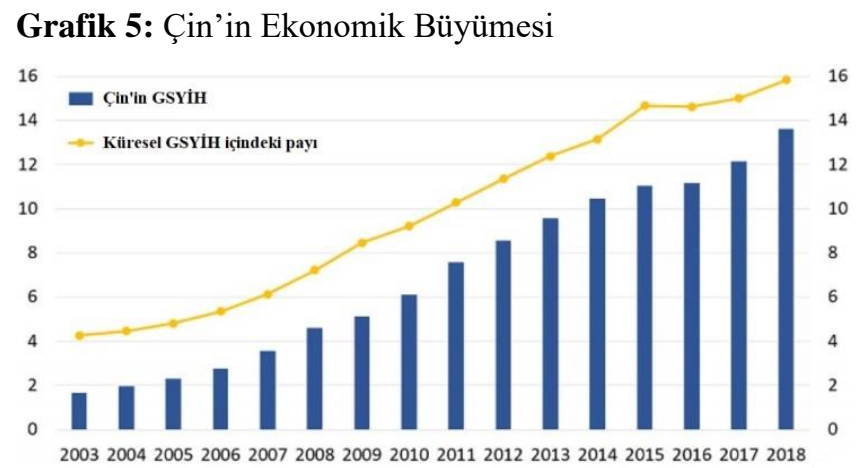

Kaynak: World Bank, 2020

Salgının Çin'de başta otomotiv üretimi olmak üzere birçok endüstriyi ciddi şekilde etkilemiş ve büyük otomobil üreticileri (Ford Motor, Fiat Chrysler, General Motor ve Tesla) üretimlerine ara vermiştir. Bu durum dünya petrol fiyatlarını da etkilemekte özellikle Çin'in 2019 yılında dünya petrol talebi artışının yarısını karşı1lıyor olması açısından önem arz etmektedir (Feuer, 2020).

Amerikan ekonomisi için yapılan bir çalışmada salgın esnasında okulların kapalı kalmasının maliyetleri hesaplanmıştır. Amerika Birleşik Devletleri'ndeki sivil işçilerin yaklaşık dörtte birinin 16 yaşından küçük bir çocuğu olduğu ve bakacak bir yetişkin olmadığı için ülkenin tüm okullarını iki hafta boyunca kapatılmasının 5,2 milyar ile 23,6 milyar dolar arasında ekonomik faaliyet kaybına yol açacağ 
ve okulların kapalı kalma süresi dört hafta olması durumunda GSYİH'nın \%0,3'üne karşılık gelen 47,1 milyar dolarlık bir maliyetin olacağı belirtilmiştir (Begley, 2013).

Salgınların GSYIHH üzerinde azaltıcı etkileri yanında arttırıcı etkileri de olabilmektedir. SARS salgınında sadece Hong Kong'da yüz maskesi için 1,5 milyar dolar harcanmıştır. Benzer şekilde, hastane ücretleri, doktor ücretleri, ilaç tedavisi ve salgınla ilgili diğer maliyetler de GSYİH'ye katkıda bulunmaktadır. 2009 yılında H1N1 (domuz gribi) ile mücadele için aşı ve ilaç satışı bazı ilaç şirketlerinin gelirlerini artırmıştır. Hafif bir salgının ortaya çıktığı 2010 yılının başlarında, Sanofi-Aventis, yıllık \% 11 artışla 10,1 milyar dolar net kar elde etmiştir (Begley, 2013).

Dünyayı uzun süre etkileyen ve kitlesel ölümlere neden olan küresel salgınlar bugün olduğu gibi, geçmişte de can kaybının yanında önemli iktisadi ve sosyal etkileri yaratmıştır. Günümüzde Covid-19 salgını ile tekrar gündeme gelen bu etkiler, tarihsel süreç içerisinde ortaya çıkan salgınlar ile birlikte değerlendirildiğinde aşağıda belirtilen sonuçlara ulaşılabilir.

- Tüm salgınların sosyal ve ekonomik yaşantıyı etkileyen etkileri olmuştur.

- Ekonomik etkilerin başında arz ve talep yanlı etkiler gelmektedir. Ölüm, hastalık ve salgının hızını azaltmak amacıyla uygulanan kısıtlamalar arz yönlü etki yaratarak üretimde azalmaya dolayısıyla enflasyona neden olmuştur. İşü̈cü arzındaki azalma, gelir düşüklüğü, tasarruflarda azalma ve dolayısıyla da yatırımlarda düşüş gözlemlenmiştir.

- Üretimin azalması ülkelerin büyüme oranlarını negatif yönde etkilerken önemli ölçüde refah kaybına yol açmıştır.

- Gelirdeki azalmaya paralel olarak temel gıdalara ulaşma sorunları ortaya çıkmıştır.

- Kisitlamalar ve salgının yayılma korkusu ülkeler arasındaki ticaret hacmini geriletmiş aynı zamanda ülkeler arasındaki ticaret, salgının yayılmasını da hızlandırmıştır. Salgından en çok etkilenen sektörler, turizm, perakende, nakliye ve hizmet sektörü olmuştur.

- Güven kaybı ve korku kaynaklı harcama eğiliminin piyasaları olumsuz etkilemesi.

- Mevcut sağlık sistemi sorgulanarak yeni tıbbi uygulamalar gündeme gelmiştir. Salgınların kaynağının belirlenmesi için yoğun çalışmalar yapılırken, salgından korunmak amaciyla karantina ve izolasyon uygulamaları olmuştur. Yeni ortaya çıkan hastalık için ayrı tıbbi üniteler ve hastaneler tesis edilirken salgını önlemeye yönelik ilaç geliştirme çalışmaları hem ulusal hem de uluslararası alanda yapılmaktadır. Tıp alanındaki gelişmeler salgınların nedenleri konusunda daha kesin bilgilere ulaşılmasına yardımcı olmuştur.

- Tarihte yaşanan büyük küresel salgınlar savaş veya ticaret gibi nedenlerle yayılırken son dönem salgınlarda ise teknolojik gelişmeye paralel olarak artan seyahatler (demiryolu ve deniz ulaşımı) bu salgınların yayılmasını hızlandırmıştır.

- Salgın ve sonrası dönemde hükümetlerin piyasayı rahatlamak amacıyla yapmış oldukları destekler kamu harcamalarını artırmıştır.

- Ekonomik açıdan bir diğer etkide salgın sonrası teknolojik tabanlı e-ticaret, lojistik, online eğitim ve evden çalışma ortamı gibi alanlarda sektörel gelişmeler olmuştur.

- Salgın hastalıklar yeni tüketim alışkanlıklarının ortaya çıkmasına yol açmıştır.

- Salgın ve sonrası dönemde yerel yönetimler ve merkezi yönetimlerin harcamalarında artış olmuştur. Ülkeler salgın döneminde yavaşlayan ekonomiyi canlandırmak amacıyla para ve maliye politikaları uygulamışlardır.

- Salgınların insan yaşantısı üzerindeki etkileri ise öncelikle göç olarak ortaya çıkmış ve göç olgusu salgınların yayılmasında önemli bir etken olmuştur. Özellikle gelir düzeyi düşük insanların şehir ve ülke değiştirmeleri birçok salgının büyümesinde tarih boyunca önemli rol oynamıştır. İnsanların salgın hastalıklardan dolayı göç etmesi yaşam tarzlarında değişme neden olmuştur.

- Salgınlarda gözlemlenen diğer bir etkide kentleşmenin artmasıdır. İnsanlar daha iyi şartlarda yaşam sunacağı beklentisiyle kentlere göç etmiştir. Fakat kentleşmeyle birlikte hastalıkların bulaşma oranları artmıştır.

- Salgınlar, sosyal hayatta dayanışmayı ön plana çıkararak yardımlaşma kurumları ve sivil toplum kuruluşlarının ortaya çıkmasına ve faaliyetlerini arttırmalarına neden olmuştur. Benzer şekilde dini kurumlarda salgın dönemlerinde faaliyetlerini arttırmışlardır. 
- İnsanların normal dönemlerde sergiledikleri faaliyetler (festivaller, fuarlar, turistik seyahatler, Hac vazifesi vs.) salgınların yayılmasını arttırmıştır.

Salgınların ardındaki itici güç tarih boyunca savaşlar, seyahatler, ticaret ve yakın zaman salgınlarında ise küreselleşme ile ön plana çıkmıştır. Gelişen dünyada, küreselleşme ve nüfus artışı doğal denge üzerinde yıkıcı etki yaratarak salgın hastalıkların yayılımını artırmıştır. Tarıma dayalı kabile toplumlardan metropollere olan dönüşüm hastalığın yayılması için firsatlar yaratmıştır. Küresel bazda yaşanan bu kriz ekonomileri ve sosyal hayatı durma noktasına getirdiğinden dolayı ülkelerin buna yönelik olarak ulusal bazda alacakları tedbirlerle olası riskleri minimize etme şansı artacaktır.

\section{Kaynakça}

Aberth, John (2010), From the Brink of the Apocalypse: Confronting Famine, War, Plague, and Death in the Later Middle Ages. Second Edition, New York: Routledge, 1-327.

AEGON (2020), "Economic Impact of the Coronavirus Crisis: What can we learn from past pandemics?", https:/www.aegonassetmanagement.com/us/thought-leadership/blog/macroresearch/economic-impact-of-the-coronavirus-crisis-what-can-we-learn-from-past-pandemics/.

Alfani, Guido (2011), "Plague In Seventeenth Century Europe And The Decline Of Italy: An Ep1demiological Hypothesis", European Review of Economic History, October, 1-47.

Alfani, Guido (2016), "Plague and Long-term Development: The Lasting Effects of the 1629-30 Epidemic on The Italian Cities", EHES Working Paper, No. 106, November, 1-37.

Al-Tawfiq, Jaffar A., Alimuddin Zumla, Ziad A. Memish (2014), "Travel implications of emerging coronaviruses: SARS and MERS-CoV", Travel Medicine and Infectious Disease, 12, 422-428.

BBC (2005), "Past Pandemics That Ravaged Europe", http://news.bbc.co.uk/2/hi/ health/4381924.stm

Bean, ohn Malcolm William, (1963), "Plague, Population and Economic Decline in England in the Later Middle Ages", The Economic History Review, New Series, Vol. 15, No. 3 (1963), pp. 423-437

Begley, Sharon (2013), "Flu-conomics: The next pandemic could trigger global recession", REUTERS, https://www.reuters.com/article/us-reutersmagazine-davos-flu-economy/flu-conomics-thenext-pandemic-could-trigger-global-recession-idUSBRE90K0F820130121

Bell, Clive, Maureen Lewis (2004), "The Economic Implications of Epidemics Old and New", World Economics, vol. 5(4), October, 1-34.

Butler, Creon (2020), “COVID-19: How Do We Re-open the Economy?", https://www.chathamhouse. org/expert/comment/covid-19-how-do-we-re-open-economy, 21 Nisan, (Erişim tarihi:21.06.2020).

CBC (2010), “Cholera's Seven Pandemics”, https://www.cbc.ca/news/technology/cholera-s-sevenpandemics-1.758504.

CDC (2004), "Basic Information about SARS", Centers for Disease Control and Prevention, January, $1-3$.

CDC (2014), "Cost of Ebola Epidemic", https://www.cdc.gov/vhf/ebola/pdf/impact-ebolaeconomy.pdf.

CDC Centers for Disease Control and Prevention (2019), "https://www.cdc.gov/flu/pandemicresources/1957-1958-pandemic.html"

CDC Centers for Disease Control and Prevention (2019), "40 Years of Ebola Virus Disease around the World", https://www.cdc.gov/vhf/ebola/history/chronology.htm.

Clark, William R. (2008), Bracing For Armageddon?, Oxford University Press, 1-211.

Cohen, Myron S., Nick Hellmann, Jay A. Levy, Kevin DeCock, Joep Lange (2008), "The spread, treatment, and prevention of HIV-1: evolution of a global pandemic", The Journal of Clinical Investigation, Volume 118 Number 4 April, 1244-1254. 
Decameron (2014), "Social and Economic Effects of the Plague", https://www.brown.edu/ Departments/Italian_Studies/dweb/plague/effects/social.php

Delivorias, Angelos, Nicole Scholz 2020), "Economic impact of epidemics and pandemics", European Parliamentary Research Service, 1-10.

Dielman, Joseph L. (2018), "Spending on health and HIV/AIDS: domestic health spending and development assistance in 188 countries, 1995-2015”, The Lancet, Vol 391 May 5, 1799-1829.

Dura, Cihan (2011), “Altın Ve Gümüş Talanı Avrupa'yı Nasıl Değiştirdi”, http://www.cihandura.com/tr/makale/-ALTIN-VE-GUMUS-TALANI-AVRUPA-YI-NASILDEGISTIRDI-697.

Elgin,C.\& Başbuğ,G. (2020), Covıd-19 Pandemisinin Yol Açtığı Ekonomık Krize Karşı Açıklanan Ekonomik Teşvık Paketleri: Bir Karşılaştırma ve Türkıye Örneğı,İstanbul Politik Araştımalar Enstitüsü,Politika Raporu, Nisan 2020 - 008.

Encyclopedia Britannica (2020), "Early modern Italy (16th to 18th centuries) The 17th-century crisis", https://www.britannica.com/place/Italy.

Euronews,https://tr.euronews.com/2020/05/08/abd-de-issizlik-yuzde-14-7-ile-buyuk-buhrandoneminden-bu-yana-en-yuksek-seviyeye-c-kt

Farris, William Wayne (2009), Japan to 1600 A Social and Economic History, University of Hawai' $i$ Press Honolulu, 1-227.

Fathers, David (2020), "London's Seen Much Worse Than Coronavirus: Remembering The Great Plague Of 1665", https://londonist.com/london/history/great-plague-1665-bloody-londondavid-fathers.

Feuer, William (2020), "Coronavirus: The hit to the global economy will be worse than SARS", https://www.cnbc.com/2020/02/06/coronavirus-the-hit-to-the-global-economy-will-be-worsethan-sars.html. CNBC, 6 Şubat.

Fischer, Colby J. (2017), "Unequal Implementation: The Impact of Government Anti-Plague Policies on the London Poor in 1665", UVM Honors College Senior Theses, 1-79

Garmaroudi, Farshid S., (2007), “The Last Great Uncontrolled Plague Of Mankınd”, The Science Creatıve Quarterly, 10.30.2007.

Henderson, D. A., Brooke Courtney, Thomas V. Inglesby, Eric Toner, Jennifer B. Nuzzo (2009), "Public Health and Medical Responses to the 1957-58 Influenza Pandemic", Biosecurity and Bioterrorism: Biodefense Strategy, Practice, and Science, Volume 7, Number 3, 265-273.

İnal,Seza (2016), "Middle East Respiratory Syndrome-Coronavirus (MERS-CoV) Enfeksiyonu: Ortadoğu Solunum Yetmezliği Sendromu-Koronavirüs Enfeksiyonu”, Okmeydanı Tıp Dergisi, 32(Ek say1):37-45.

Joo, Heesoo, Brian A. Maskery, Andre D. Berro, Lisa D. Rotz, Yeon-Kyeng Lee, Clive M. Brown, (2019), "Economic impact of the 2015 MERS outbreak on the Republic of Korea's tourismrelated industries", Health Secur, 17(2), 100-108.

Karakuş, Onur Sadık (2018), "Doğu'dan Gelen Ölüm: Antoninus Vebası”, Toplumsal Tarih, 296, Ağustos, 38-41.

Kessler, Robert (2020), "SARS: The First Pandemic of the 21st Century”, https://www. ecohealthalliance.org/2018/03/sars

Kim, Yang-Woo, Seok-Jun Yoon, In-Hwan Oh, (2013), "The economic burden of the 2009 pandemic H1N1 influenza in Korea", Scandinavian Journal of Infectious Diseases, 45: 390-396.

Küçükşehir, Erdal (2020), "Virüs ekonomisi", https://www.bbnhaber.com/yazi/virus-ekonomisi, (Erişim tarihi: 10.05 .2020$)$ 
Lee, Kelley, Richard Dodgson, "Globalization and Cholera: Implications for Global Governance", Global Governance, Vol. 6, No. 2 (Apr.-June), 213-236.

Lee, Yen Nee (2020), "4 charts show how SARS hit China's economy nearly 20 years ago", https://www.cnbc.com/2020/02/11/coronavirus-4-charts-show-how-sars-hit-chinas-economyin-2003.html. CNBC 10 Şubat.

LePan, Nicholas (2020), "Visualizing the History of Pandemics", https://www. visualcapitalist.com/history-of-pandemics-deadliest/.

Matillano, Hadley (2011), "The Effect of Smallpox on the New World", Historical Paper, Junior Division, World Count: 2398, 1-21.

McKibbin, Warwick, J. (2009), "The Swine Flu Outbreak and its Global Economic Impact", https://www.brookings.edu/on-the-record/the-swine-flu-outbreak-and-its-global-economicimpact/.

Meier, Mischa (2016), “The 'Justinianic Plague': The Economic Consequences of the Pandemic in the Eastern Roman Empire and its Cultural and Religious Effects", Early Medieval Europe, 24 (3), 267-292

MercyCorps (2019), "Chapter 4: How does Ebola affect the economy?", www.mercycorps. org/blog/ebola-outbreaks-africa-guide/chapter-4

Mitchener, Kris James, Marc D. Weidenmier (2007), "The Baring Crisis and the Great Latin American Meltdown of the 1890s", The Journal of Economic History, Vol. 68, No. 2 (Jun., 2008), 462500 .

Pamuk, Şevket (2020), “Tarihte Küresel Salgınlar ve İktisadi Sonuçları”, https://sarkac.org/ 2020/04/tarihte-kuresel-salginlar-ve-iktisadi-sonuclari/

Patterson, David K. (1992), "Yellow Fever Epidemics and Mortality in The United States, 1693-1905", Social Science \& Medical, Vol. 34, No. 8, 855-865.

Riedel, Stefan (2005), "Edward Jenner and The History of Smallpox and Vaccination", BUMC Proceeding, 18, 21-25.

Roberts, J. A., P. Cumberland, P. N. Sockett, J. Wheeler, L. C. Rodrigues, D. Sethı, P. J. Roderıck, (2003), "The Study of Infectious Intestinal Disease in England: Socio-economic Impact", Epidemiol. Infect. 130, Cambridge University Press, 1-11.

Rosenwald, Michael S., (2020), "History's Deadliest Pandemics, From Ancient Rome to Modern America", https://www.washingtonpost.com/graphics/2020/local/retropolis/ coronavirusdeadliest-pandemics/.

Roser, Max (2020), "The Spanish flu (1918-20): The global impact of the largest influenza pandemic in history", https://ourworldindata.org/spanish-flu-largest-influenza-pandemic-in-history.

Sabbatini, Sergio, Sirio Fiorino (2009), "La peste antonina e il declino dell'Impero Romano. Ruolo della guerra partica e della guerra marcomannica tra il 164 e il 182 d.C. nella diffusione del contagio", Le Infezioni in Medicina, n. 4, 261-275

Sağlık Bakanlığı (2020), "Ebola”, www.seyahatsagligi.gov.tr/site/HastalikDetay/Ebola

Sanburn, Josh (2010), “The Third Plague Pandemic”, TIME, Tuesday, Oct. 26.

Saunders-Hastings, Patrick R. Daniel Krewski (2016), "Reviewing the History of Pandemic Influenza: Understanding Patterns of Emergence and Transmission", Pathogens, 5, 66, 1-19.

SB (2020), "Hong Kong Flu (1968 Influenza Pandemic)", https://www.sinobiological.com /research/virus/1968-influenza-pandemic-hong-kong-flu.

Snell, Melissa (2019), “The Sixth-Century Plague”, ThoughtCo, Feb. 11, 2020, thoughtco.com/thesixth-century-plague-1789291. 
Stenseth, Nils Chr. (2008), “Plague Through History”, Science, Vol, 321, 8 August, 773-774.

Stepan, Nancy (1978), "The Interplay Between Socio-Economic Factors and Medical Science: Yellow Fever Research, Cuba and the United States", Social Studies of Science, Vol 8, 397-423.

The Economist (2009), "The cost of swine flu", https://www.economist.com/news/2009/ 07/27/the-cost-of-swine-flu.

Tognotti, Eugenia (2010), "The eradication of smallpox, a success story for modern medicine and public health: What lessons for the future?", J Infect Dev Ctries, 4(5), 264-266.

UN (1960), World Economic Survey 1959, United Natıons Department Of Economic and Social Affairs, New York, 1-250.

Uzluk, Feridun Nafiz (1948), “Cholera Asiaticanın Epidemi Tarihi Üstüne Bir Araştırma”, Türk Ljiyen ve Tecrübi Biyoloji Dergisi, Cilt 8, Sayı 1, 7-36.

World Bank (2020), "GDP (current US\$) - China”, https://data.worldbank.org/ indicator/NY.GDP.MKTP.CD?end=2019\&locations=CN\&start=2003. (Erişim tarihi: 20.05.2020).

Wha, Jong-Lee \& Warwick J. McKibbin (2004), Learning from SARS: Preparing for the Next Disease Outbreak, içinde "Estimating The Global Economic Costs of SARS", Edt: Stacey Knobler, Adel Mahmoud, Stanley Lemon, Alison Mack, Laura Sivitz, and Katherine Oberholtzer, The National Academies Press, 91-109.

WHO (2009), "Who Guide to Identifying The Economic Consequences of Disease and Injury", Department of Health Systems Financing Health Systems and Services,

WHO (2020), "Global Health Observatory (GHO) data”, https://www.who.int/gho/hiv/en/

Verikios, George, Maura Sullivan, Pane Stojanovski, James Giesecke, Gordon Woo (2011), "The Global Economic Effects of Pandemic Influenza", 14th Annual Conference on Global Economic Analysis, Venice, June 16-18, 1-41. 